\title{
Well-Defined 2:1 and 2:2 Arylcopper-Copper Bromide Aggregates and Selective Biaryl Formation
}

\author{
Maurits D. J anssen, ${ }^{\dagger}$ Michael A. Corsten, ${ }^{\dagger}$ Anthony L. Spek, ${ }^{\ddagger, \S}$ \\ David M. Grove, ${ }^{\dagger}$ and Gerard van Koten*, $\dagger$ \\ Debye Institute, Department of Metal-Mediated Synthesis, and Bijvoet Center for Biomolecular \\ Research, Department of Crystal and Structural Chemistry, Utrecht University, \\ Padualaan 8, $3584 \mathrm{CH}$ Utrecht, The Netherlands
}

Received J anuary 29, $1996^{\otimes}$

\begin{abstract}
Reaction of tetranuclear $\left[\mathrm{Li}_{4}\left(\mathrm{C}_{6} \mathrm{H}_{4} \mathrm{CH}_{2} \mathrm{NMe}_{2}-2\right)_{4}\right]$ (1) with $4 / 3$ equiv of the copper(I) arenethiolate $\left[\mathrm{Cu}_{3}\left(\mathrm{SC}_{6} \mathrm{H}_{4} \mathrm{NM} \mathrm{N}_{2}-2\right)_{3}\right]$ (2) results in the quantitative formation of the aryl copper compound $\left[\mathrm{Cu}_{4}\left(\mathrm{C}_{6} \mathrm{H}_{4} \mathrm{CH}_{2} \mathrm{NMe}_{2}-2\right)_{4}\right]$ (3) and the lithium arenethiolate $\left[\mathrm{Li}\left(\mathrm{SC}_{6} \mathrm{H}_{4} \mathrm{NMe}_{2}-2\right)\right]_{n}$ (4). The arylcopper species $\mathbf{3}$ is a yellow air-sensitive solid, which is tetrameric in the solid state as well as in solution. The reaction of the dinuclear aryllithium reagent $\left[\mathrm{Li}_{2}\left\{\mathrm{C}_{6} \mathrm{H}_{4^{-}}\right.\right.$ $\left.\left(\mathrm{CH}_{2} \mathrm{~N}(\mathrm{Me}) \mathrm{CH}_{2} \mathrm{CH}_{2} \mathrm{NMe}_{2}\right)-2\right\}_{2}$ ] (5) with 3 equiv of $\mathrm{CuBr}$ affords the trinuclear mixed 2:1 arylcopper-copper bromide aggregate $\left[\mathrm{Cu}_{3} \mathrm{Br}\left\{\mathrm{C}_{6} \mathrm{H}_{4}\left(\mathrm{CH}_{2} \mathrm{~N}(\mathrm{Me}) \mathrm{CH}_{2} \mathrm{CH}_{2} \mathrm{NMe}_{2}\right)-2\right\}_{2}\right]$ (6). The 1:4 reaction of 5 with $\mathrm{CuBr}$ affords the tetranuclear mixed 2:2 aggregate $\left[\mathrm{Cu}_{4} \mathrm{Br}_{2-}\right.$ $\left.\left\{\mathrm{C}_{6} \mathrm{H}_{4}\left(\mathrm{CH}_{2} \mathrm{~N}(\mathrm{Me}) \mathrm{CH}_{2} \mathrm{CH}_{2} \mathrm{NMe}_{2}\right)-2\right\}_{2}\right]$ (7). As solids, aggregates 6 and 7 are less air-sensitive than 3, but their solutions rapidly turn green upon exposure to air. The 1:2 reaction of the naphthyllithium reagent [ $\left.\mathrm{Li}\left\{1-\mathrm{C}_{10} \mathrm{H}_{6}\left(\mathrm{CH}_{2} \mathrm{~N}(\mathrm{Me}) \mathrm{CH}_{2} \mathrm{CH}_{2} \mathrm{NMe}_{2}\right)-2\right\}\right]$ (9) with $\mathrm{CuBr}$ affords the tetranuclear mixed 2:2 aggregate $\left[\mathrm{Cu}_{4} \mathrm{Br}_{2}\left\{1-\mathrm{C}_{10} \mathrm{H}_{6}\left(\mathrm{CH}_{2} \mathrm{~N}(\mathrm{Me}) \mathrm{CH}_{2} \mathrm{CH}_{2} \mathrm{NMe}_{2}\right)-2\right\}_{2}\right]$ (10), in which there is a 1:1 aryl copper to copper bromide ratio. Aggregate $\mathbf{1 0}$ is obtained as brownish yellow crystals, and solutions of $\mathbf{1 0}$ slowly turn bluish green upon exposure to air. The molecular structures of $\mathbf{6}$ and $\mathbf{1 0}$ both contain an R-Cu-R fragment and can be described as comprising a $\left[\mathrm{CuR}_{2}\right]^{-}$unit stabilized by a $\left[\mathrm{Cu}_{2} \mathrm{Br}\right]^{+}$or a $\left[\mathrm{Cu}_{3} \mathrm{Br}_{2}\right]^{+}$cation, respectively. Heating solutions of $6\left(55^{\circ} \mathrm{C} ; 15 \mathrm{~min}\right)$ and solutions of $\mathbf{1 0}\left(110^{\circ} \mathrm{C} ; 19 \mathrm{~h}\right)$ results in quantitative biaryl (6) and moderate binaphthyl (10) formation, respectively. The relevance of neutral aggregates such as 6, 7, and $\mathbf{1 0}$ as model complexes both for the interpretation of bonding in higher order cuprate species and for understanding of their reactivity is discussed.
\end{abstract}

\section{Introduction}

In the course of our studies in synthetic organocopper chemistry we have reported mixed 2:2, 2:3, and 4:2 organocopper-copper halide aggregates with the formulations $\left[\mathrm{Cu}_{4} \mathrm{Br}_{2} \mathrm{R}_{2}\right],\left[\mathrm{Cu}_{5} \mathrm{Br}_{3} \mathrm{R}_{2}\right]$, and $\left[\mathrm{Cu}_{6} \mathrm{Br}_{2} \mathrm{R}_{4}\right]$, respectively. ${ }^{1-4}$ More recently, we have also synthesized and fully characterized several other mixed organocopper-copper pseudohalide aggregates: i.e. trinuclear $1: 2$ $\left[\mathrm{Cu}_{3}\left(\mathrm{O}_{2} \mathrm{CPh}\right)_{2}(\mathrm{R})\right]_{,}{ }^{5}$ tetranuclear 2:2 $\left[\mathrm{Cu}_{4}(\mathrm{SAr})_{2}(\mathrm{R})_{2}\right]^{6}{ }^{6}$ and hexanuclear 2:4 $\left[\mathrm{Cu}_{6}(\mathrm{SAr})_{4}\left(\mathrm{R}^{\prime}\right)_{2}\right]^{7}\left(\mathrm{SAr}=\mathrm{SC}_{6} \mathrm{H}_{4}{ }^{-}\right.$ $\left(\mathrm{CH}\left(\mathrm{R}^{\prime \prime}\right) \mathrm{NMe}_{2}\right)-2, \mathrm{R}=\mathrm{C}_{6} \mathrm{H}_{2} \mathrm{Me}_{3}-2,4,6, \mathrm{R}^{\prime}=\mathrm{C} \equiv \mathrm{C}^{\mathrm{t}} \mathrm{Bu}$, $R^{\prime \prime}=H, M e$ ) as well as hexanuclear mixed 4:2 organocopper aggregates $\left[\mathrm{Cu}_{6}(\mathrm{R})_{4}\left(\mathrm{R}^{\prime}\right)_{2}\right]^{8}$

* To whom correspondence should be addressed. E-mail: vankoten@xray.chem.ruu.nl.

$\dagger$ Debye Institute.

₹ Bijvoet Center for Biomolecular Research.

$\S$ To whom correspondence pertaining to crystallographic studies should be addressed. E-mail: spea@xray.chem.ruu.nl.

${ }^{\otimes}$ Abstract published in Advance ACS Abstracts, May 1, 1996.

(1) Tetranuclear 2:4 [ $\left.\mathrm{Cu}_{4} \mathrm{Br}_{2}(\mathrm{aryl})_{2}\right]$ aggregate: Wehman, E.; van Koten, G.; Erkamp, C. J . M.; Knotter, D. M.; J astrzebski, J . T. B. H.; Stam, C. H. Organometallics 1989, 8, 94-99.

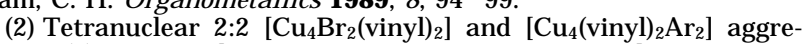
gates: (a) ten Hoedt, R. W. M.; van Koten, G.; Noltes, J. G. J . Organomet. Chem. 1978, 161, C13-C16. (b) ten Hoedt, R. W. M.; van Koten, G.; Noltes, J. G. J . Organomet. Chem. 1979, 179, 227-240. (c) ten Hoedt, R. W. M.; van Koten, G.; Noltes, J . G. J . Organomet. Chem. 1980, 201, 327-342.

(3) Pentanuclear 2:3 $\left[\mathrm{Cu}_{5} \mathrm{Br}_{3}(\operatorname{aryl})_{2}\right]$ aggregate: Kapteijn, G. M.; Wehman-Ooyevaar, I. C. M.; Grove, D. M.; Smeets, W. J . J .; Spek, A. L.; van Koten, G. Angew. Chem., Int. Ed. Engl. 1993, 32, 72-73.
This paper deals with the synthesis and characterization of arylcopper compounds with intramolecularly coordinating amine functionalities. During reactivity studies of these species we have encountered interesting cases of selective biaryl formation from aggregated arylcopper and copper bromide units. These results reported here show for the first time a direct connection between the structures of mixed tri- and tetranuclear copper aggregates and selective $\mathrm{C}-\mathrm{C}$ coupling reactions. Moreover, the structural features of these aggregates

(4) Hexanuclear 4:2 $\left[\mathrm{Cu}_{6} \mathrm{Br}_{2}(\mathrm{aryl})_{4}\right]$ aggregate: (a) Guss, J. M.; Mason, R.; Thomas, K. M.; van Koten, G.; N oltes, J . G. J . Organomet. Chem. 1972, 40, C79-C80. (b) Leusink, A. J .; van Koten, G.; Noltes, J. G. J . Organomet. Chem. 1973, 56, 379-390. (c) van Koten, G. Leusink, A. J .; Noltes, J . G. J . Organomet. Chem. 1975, 85, 105-114. (d) van Koten, G.; Noltes, J . G. J . Organomet. Chem. 1975, 102, 551563. [ $\left.\mathrm{Cu}_{6} \mathrm{Br}_{2}\{\mathrm{oxl}\}_{4}\right]$ : (e) Wehman, E.; van Koten, G.; J astrzebski, J . T. B. H.J . Organomet. Chem. 1986, 302, C35-C39. (f) Wehman, E.; van Koten, G.; J astrzebski, J . T. B. H.; Rotteveel, M. A.; Stam, C. H. Organometallics 1988, 7, 1477-1485.

(5) Trinuclear 1:2 [ $\left.\mathrm{Cu}_{3}\left(\mathrm{O}_{2} \mathrm{CPh}\right)_{2}(\mathrm{Mes})\right]$ aggregate: (a) Aalten, $\mathrm{H}$. L.; van Koten, G.; Goubitz, K.; Stam, C. H.J . Chem. Soc., Chem. Commun. 1985, 1252-1253. (b) Aalten, H. L.; van Koten, G.; Goubitz, K.; Stam, C. H. Organometallics 1989, 8, 2293-2299.

(6) Tetranuclear 2:2 $\left[\mathrm{Cu}_{4}(\mathrm{SAr})_{2}(\mathrm{Mes})_{2}\right]$ aggregate: Knotter, D. M. Grove, D. M.; Smeets, W. J .J .; Spek, A. L.; van Koten, G. J . Am. Chem. Soc. 1992, 114, 3400-3410.

(7) Hexanuclear 2:4 [ $\left.\mathrm{Cu}_{6}(\mathrm{SAr})_{4}\left(\mathrm{C} \equiv \mathrm{C}^{\mathrm{t}} \mathrm{Bu}\right)_{2}\right]$ aggregate: Knotter, $\mathrm{D}$. M.; Spek, A. L.; Grove, D. M.; van Koten, G. Organometallics 1992, 11, 4083-4090.

(8) Hexanuclear $\left[\mathrm{Cu}_{6}(\operatorname{aryl})_{4}(\mathrm{C} \equiv \mathrm{CR})_{2}\right]$ aggregate: (a) van Koten, $\mathrm{G}$.; Noltes, J . G. J . Chem. Soc., Chem. Commun. 1974, 575-576. (b) van Koten, G.; ten Hoedt, R. W. M.; Noltes, J . G. J . Org. Chem. 1977, 42, 2705-2711. (c) ten Hoedt, R. W. M.; Noltes, J. G.; van Koten, G. J . Chem. Soc., Dalton Trans. 1978, 1800-1806. 
comprising $\left[\mathrm{CuR}_{2}\right]^{-}$and $\left[\mathrm{Cu}_{\mathrm{x}+1} \mathrm{Br}_{\mathrm{x}}\right]^{+}$building blocks may be used to illustrate the nature of kinetic intermediates such as $\left[\mathrm{Li}_{2} \mathrm{Cu}(\mathrm{CN})(\mathrm{Ar})\left(\mathrm{Ar} \mathrm{r}^{\prime}\right)\right]$, proposed to be the active species in higher order cuprate biaryl coupling reactions.

\section{Results}

Preparation of $\left[\mathrm{Cu}_{4}\left(\mathrm{C}_{6} \mathrm{H}_{4} \mathrm{CH}_{2} \mathrm{NMe}_{2}-2\right)_{4}\right]$ (3). Reaction of $\left[\mathrm{Li}_{4}\left(\mathrm{C}_{6} \mathrm{H}_{4} \mathrm{CH}_{2} \mathrm{NMe}_{2}-2\right)_{4}\right](\mathbf{1})^{9}$ with the copper arenethiolate $\left[\mathrm{Cu}_{3}\left(\mathrm{SC}_{6} \mathrm{H}_{4} \mathrm{NMe}_{2}-2\right)_{3}\right](2)^{10}$ in a 3:4 ratio (based on aggregate) results in the quantitative formation of $\left[\mathrm{Cu}_{4}\left(\mathrm{C}_{6} \mathrm{H}_{4} \mathrm{CH}_{2} \mathrm{NMe}_{2}-2\right)_{4}\right]$ (3) and the insoluble lithium arenethiolate $\left[\mathrm{Li}\left(\mathrm{SC}_{6} \mathrm{H}_{4} \mathrm{NMe}_{2}-2\right)\right]_{\mathrm{n}}$ (4) (eq 1). ${ }^{11}$

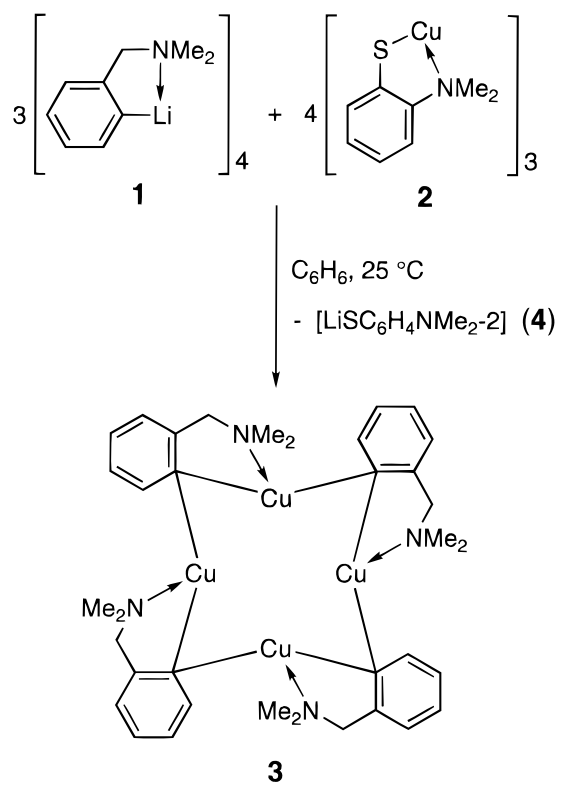

The synthesis of $\mathbf{3}$ was al ready reported; ${ }^{12}$ however, the yield was low (44\%) and this was ascribed to the formation of intermediate aggregates of $\mathbf{3}$ with $\mathrm{CuBr}$ (eg. [3. $\mathrm{CuBr}$ ]) which are unstable under the reaction conditions employed. In our new synthetic method mixed organo(arenethiolato)copper aggregates [ $\mathrm{Cu}_{x^{-}}$ $\left.(\mathrm{SAr})_{y}(\mathrm{R})_{x-y}\right]_{n}$ or hetero cuprates [LiCu(SAr)(R)], often formed in related reactions, ${ }^{6}$ are not generated: i.e., the monoani onic arenethiol ate ligand is cleanly transferred from $\mathrm{Cu}^{\prime}$ to the more electropositive lithium.

The pure arylcopper $\mathbf{3}$ has been isol ated in very high yield as bright yellow, air-sensitive crystals, and its solutions turn green within $10 \mathrm{~min}$ upon exposure to air. Complex 3 is readily soluble in $\mathrm{Et}_{2} \mathrm{O}, \mathrm{THF}$, benzene, and toluene, but it is only slightly soluble in pentane and hexane. Cryoscopic molecular weight determinations in benzene show 3 to exist as a tetramer in this solvent.

Structure of $\left[\mathrm{Cu}_{4}\left(\mathrm{C}_{6} \mathrm{H}_{4} \mathrm{CH}_{2} \mathrm{NMe}_{2}-2\right)_{4}\right]$ (3) in the Solid State. ${ }^{13}$ The molecular structure of arylcopper

(9) (a) J astrzebski, J . T. B. H.; van Koten, G. Inorg. Synth. 1989, 26, 150-155. (b) J astrzebski, J . T. B. H.; van Koten, G.; Konijn, M.; Stam, C. H. J . Am. Chem. Soc. 1982, 104, 5490-5492.

(10) J anssen, M. D.; Donkervoort, J . G.; van Berlekom, S. B.; Spek, A. L.; Grove, D. M.; van Koten, G. Inorg. Chem., in press.

(ii) Details on several lithium arenethiolate complexes [ $\mathrm{Li}(\mathrm{SAr})]_{\mathrm{n}}$ are included in: J anssen, M. D.; Rijnberg, E.; de Wolf, C. A.; Hogerheide, M. P.; Kruis, D.; Kooijman, H.; Spek, A. L.; Grove, D. M.; van Koten, G. Inorg. Chem., submitted for publication.

(12) (a) van Koten, G.; Leusink, A. J .; Noltes, J . G. J . Chem. Soc., Chem. Commun. 1970, 1107-1108. (b) Guss, J . M.; Mason, R.; Søtofte, I.; van Koten, G.; Noltes, J. G. J . Chem. Soc., Chem. Commun. 1972, 446. (c) van Koten, G.; Noltes, J. G. J . Organomet. Chem. 1975, 84, 129-138.
Table 1. Selected Geometrical Details of $\left[\mathrm{Cu}_{4}\left(\mathrm{C}_{6} \mathrm{H}_{4} \mathrm{CH}_{2} \mathrm{NMe}_{2}-2\right)_{4}\right] \cdot \mathrm{THF}(3 \cdot \mathrm{THF})^{\mathrm{a}}$

\begin{tabular}{|c|c|c|c|}
\hline \multicolumn{4}{|c|}{ Bond Distances $(\AA)$} \\
\hline Cu1-C11 & $2.087(2)$ & Cul-N1 & $2.165(2)$ \\
\hline $\mathrm{Cu} 2-\mathrm{C} 11$ & $2.007(2)$ & $\mathrm{Cu} 2-\mathrm{N} 2$ & $2.205(2)$ \\
\hline $\mathrm{Cu} 2-\mathrm{C} 21$ & $2.102(2)$ & 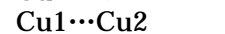 & $2.3885(3)$ \\
\hline Cula-C21 & $1.994(2)$ & Cu1 $\cdots$ Cu2a & $2.3728(3)$ \\
\hline \multicolumn{4}{|c|}{ Bond Angles (deg) } \\
\hline Cu1-C11-Cu2 & $71.35(8)$ & $\mathrm{N} 1-\mathrm{Cu} 1-\mathrm{C} 21 \mathrm{a}$ & 108.58(8) \\
\hline Cu2-C21-Cula & $70.74(7)$ & $\mathrm{C} 11-\mathrm{Cu} 2-\mathrm{C} 21$ & $156.3(1)$ \\
\hline C11-Cu1-N1 & $85.63(8)$ & $\mathrm{C} 11-\mathrm{Cu} 2-\mathrm{N} 2$ & $105.82(8)$ \\
\hline C11-Cu1-C21a & 161.6(1) & $\mathrm{C} 21-\mathrm{Cu} 2-\mathrm{N} 2$ & 85.79(8) \\
\hline
\end{tabular}

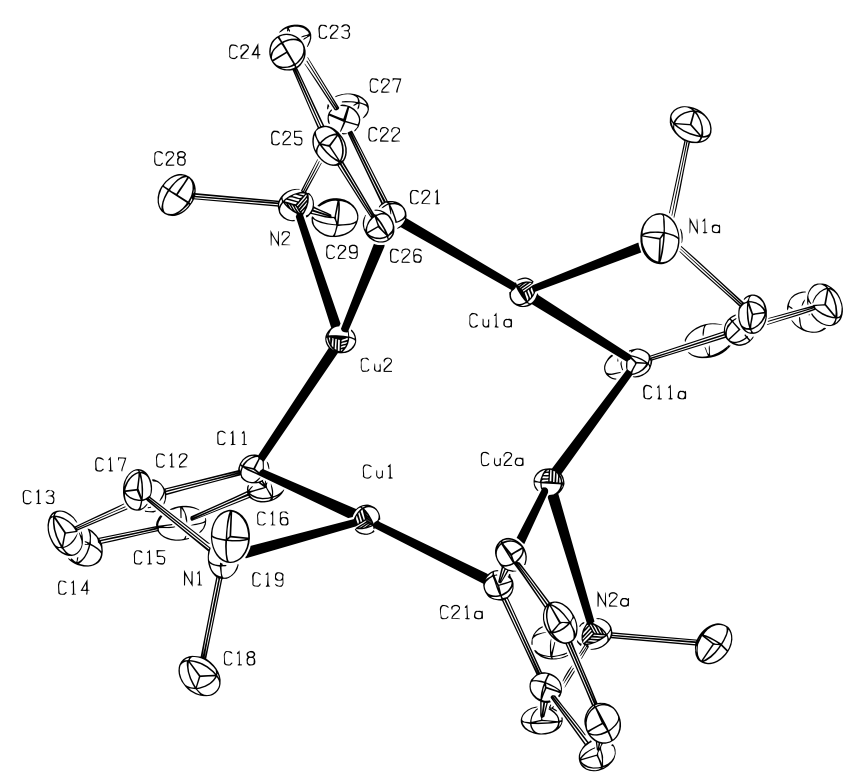

Figure 1. ORTEP drawing (thermal ellipsoids at $30 \%$ probability) of $\left[\mathrm{Cu}_{4}\left(\mathrm{C}_{6} \mathrm{H}_{4} \mathrm{CH}_{2} \mathrm{NMe}_{2}-2\right)_{4}\right] \cdot \mathrm{THF}$ (3.THF) (with the exclusion of the hydrogen atoms and the disordered THF solvate molecule) with the atom-labeling scheme.

complex $\mathbf{3}$ was established by means of X-ray diffraction techniques, and selected geometrical details are listed in Table 1. In the structure there is a crystallographic 2 -fold rotation axis along the $b$ axis of the unit cell, perpendicular to the least-squares plane through the copper atoms.

In the solid state complex $\mathbf{3}$ has a tetranuclear structure in which the four copper atoms are in an openbutterfly arrangement (Figure 1), where the angle between the planes defined by the "wings" Cu1, Cu2, Cu2a and Cula, Cu2, Cu2a is 30.67(1) ${ }^{\circ}$. Each copper atom in $\mathbf{3}$ is bonded to two $\mu$ - $\mathrm{C}_{\text {ipso }}$ (aryl) atoms and also coordinated by one (dimethylamino)methyl nitrogen atom (Cu1-N 1 and Cu2-N2 are 2.165(2) and 2.205(2) $\AA$, respectively), such that each copper atom has a distorted-trigonal-planar geometry $\left(\Sigma^{\circ} \mathrm{Cu} 1=355.9^{\circ}\right.$; $\Sigma_{\text {Cu2 }}^{\circ}=347.9^{\circ}$ ).

The $\mathrm{C}_{\text {ipso }}($ aryl) to copper distances fall in the range $1.994(2)-2.102(2) \AA$ and can be considered normal for bridging units in aryl copper species. The [(dimethylamino)methyl]phenyl ligands each bridge two copper atoms, and the corresponding $\mathrm{Cu}-\mathrm{C}-\mathrm{Cu}$ angles are rather acute $\left(71.35(8)\right.$ and $70.74(7)^{\circ}$ for Cu1-C11-Cu2

(13) The crystal structure of $\left[\mathrm{Cu}_{4}\left(\mathrm{C}_{6} \mathrm{H}_{3} \mathrm{CH}_{2} \mathrm{NMe}_{2}-2-\mathrm{Me}-5\right)_{4}\right]$, which is related to 3 , has al ready been reported, 12b,c but full crystallographic data have never been presented. 
and $\mathrm{Cu} 2-\mathrm{C} 21-\mathrm{Cu}$ a, respectively). Similar acute $\mathrm{Cu}-$ $\mathrm{C}-\mathrm{Cu}$ angles have been reported earlier and are typical for two-electron-three-center (2e-3c) bonding of an aryl group to two copper atoms. ${ }^{8 c, 12}$ The $\mathrm{Cu} \cdot \cdots$ Cu distances in 3 are 2.3728(3) and 2.3885(3) $\AA$ and are among the shortest reported for arylcopper species and copper(I) complexes in general.

Preparation of Mixed Arylcopper-Copper Bromide Aggregates $\left[\mathrm{Cu}_{3} \mathrm{BrR}_{2}\right](6 ; 2: 1)^{14}$ and $\left[\mathrm{Cu}_{4} \mathrm{Br}_{2} \mathrm{R}_{2}\right]$ (7; 2:2). Reaction of 1 equiv of dinuclear $\left[\mathrm{Li}_{2}\left\{\mathrm{C}_{6} \mathrm{H}_{4}\right.\right.$ $\left.\left.\left(\mathrm{CH}_{2} \mathrm{~N}(\mathrm{Me}) \mathrm{CH}_{2} \mathrm{CH}_{2} \mathrm{NMe}_{2}\right)-2\right\}_{2}\right]$ (5) ${ }^{15}$ with 3 equiv of copper(I) bromide affords the trinuclear mixed 2:1 organocopper-copper bromide aggregate $\left[\mathrm{Cu}_{3} \mathrm{Br}\right.$ $\left.\left\{\mathrm{C}_{6} \mathrm{H}_{4}\left(\mathrm{CH}_{2} \mathrm{~N}(\mathrm{Me}) \mathrm{CH}_{2} \mathrm{CH}_{2} \mathrm{NMe}_{2}\right)-2\right\}_{2}\right]$ (6) (eq 2).

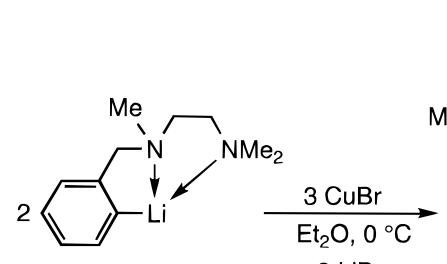

5
6

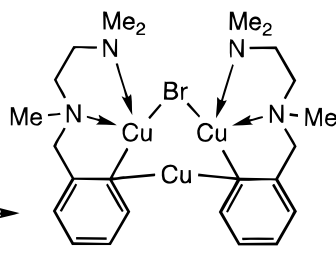

Complex $\mathbf{6}$ has been isolated as yellow crystals and, like 3, its solutions turn green upon exposure to air. Solid 6 has a higher resistance to hydrolysis and oxidation than $\mathbf{3}$, and solid $\mathbf{6}$ is not visibly changed after exposure to air for $30 \mathrm{~min}$. Complex $\mathbf{6}$ is soluble in the same common organic solvents as $\mathbf{3}$ and is insoluble in pentane and hexane.

The reaction of 1 equiv of dinuclear $\left[\mathrm{Li}_{2}\left\{\mathrm{C}_{6} \mathrm{H}_{4}\right.\right.$ $\left.\left(\mathrm{CH}_{2} \mathrm{~N}(\mathrm{Me}) \mathrm{CH}_{2} \mathrm{CH}_{2} \mathrm{NMe}_{2}\right)-2\right\}_{2}$ ] (5) ${ }^{15}$ with less than 3 equiv of $\mathrm{CuBr}$ also leads to the formation of $\mathbf{6}$, although in lower yields. However, when 1 equiv of dinuclear $\mathbf{5}$ is reacted with 4 equiv of $\mathrm{CuBr}$, one obtains a tetranuclear mixed 2:2 $\left[\mathrm{Cu}_{4} \mathrm{Br}_{2}\left\{\mathrm{C}_{6} \mathrm{H}_{4}\left(\mathrm{CH}_{2} \mathrm{~N}(\mathrm{Me}) \mathrm{CH}_{2} \mathrm{CH}_{2}\right.\right.\right.$ $\mathrm{NMe}_{2}$ )-2 $\}_{2}$ ] aggregate (7) (eq 3).

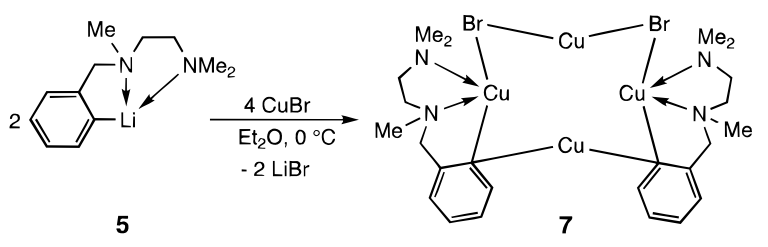

Complex $\mathbf{7}$ is isolated as a greenish yellow solid that has solubility properties similar to those of $\mathbf{6}$ (vide supra). Solutions of $\mathbf{6}$ and $\mathbf{7}$ in benzene are stable for many hours at room temperature under a $\mathrm{N}_{2}$ atmosphere and show no tendency to form precipitates of poorly soluble $\mathrm{CuBr}$.

Attempted syntheses of the pure arylcopper species [CuR]n $\left(\mathrm{R}=\mathrm{C}_{6} \mathrm{H}_{4}\left(\mathrm{CH}_{2} \mathrm{~N}(\mathrm{Me}) \mathrm{CH}_{2} \mathrm{CH}_{2} \mathrm{NMe}_{2}\right)-2\right)$, by reaction of aryllithium reagent $\mathbf{5}$ with copper(I) arenethiolate 2, unfortunately did not result in the formation of a single isolable arylcopper complex; instead, a mixture

(14) (a) The synthesis and structural features of 6 have been communicated at the XVIth International Conference on Organometallic Chemistry, Brighton, U.K., J uly 10-15, 1994, Abstract OC.9. (b) Furthermore, see: van Koten, G.; J ames, S. L.; J astrzebski, J . T. B. H. In Comprehensive Organometallic Chemistry II; Abel, E. W., Stone, F. G. A., Wilkinson, G., Eds.; Pergamon: Oxford, U.K., 1995; Vol. 3, Chapter 2, pp 57-133.

(15) Rietveld, M. H. P.; Wehman-Ooyevaar, I. C. M.; Kapteijn, G. M.; Grove, D. M.; Smeets, W. J . J .; Kooijman, H.; Spek, A. L.; van Koten, G. Organometallics 1994, 13, 3782-3787.
Table 2. Selected Geometrical Details of $\left[\mathrm{Cu}_{3} \mathrm{Br}\left\{\mathrm{C}_{6} \mathrm{H}_{4}\left(\mathrm{CH}_{2} \mathrm{~N}(\mathrm{Me}) \mathrm{CH}_{2} \mathrm{CH}_{2} \mathrm{NMe}_{2}\right)-2\right\}_{2}\right](6)^{\mathrm{a}}$

\begin{tabular}{|c|c|c|c|}
\hline \multicolumn{4}{|c|}{ Bond Distances $(\AA)$} \\
\hline Cul-C11 & $2.108(5)$ & $\mathrm{Cu} 2-\mathrm{N} 22$ & $2.169(5)$ \\
\hline Cu3-C11 & $1.956(6)$ & Cul-Brl & $2.432(1)$ \\
\hline $\mathrm{Cu}-\mathrm{C} 21$ & $1.978(5)$ & $\mathrm{Cu} 2-\mathrm{Br} 1$ & $2.4169(8)$ \\
\hline $\mathrm{Cu} 2-\mathrm{C} 21$ & $2.081(5)$ & cu1 $\cdots$ cu3 & $2.4090(9)$ \\
\hline Cu1-N11 & $2.224(5)$ & 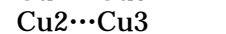 & $2.403(1)$ \\
\hline Cu1-N12 & $2.158(5)$ & Cu1...cu2 & $3.299(1)$ \\
\hline Cu2-N21 & $2.271(4)$ & & \\
\hline \multicolumn{4}{|c|}{ Bond Angles (deg) } \\
\hline Cu1-C11-Cu3 & $72.6(2)$ & $\mathrm{C} 11-\mathrm{Cu} 1-\mathrm{N} 12$ & $109.4(2)$ \\
\hline $\mathrm{Cu} 2-\mathrm{C} 21-\mathrm{Cu} 3$ & $72.6(2)$ & $\mathrm{C} 21-\mathrm{Cu} 2-\mathrm{Br} 1$ & $144.0(2)$ \\
\hline Cu1-Br1-Cu2 & $85.75(3)$ & $\mathrm{N} 21-\mathrm{Cu} 2-\mathrm{Br} 1$ & $110.7(1)$ \\
\hline C11-Cu1-Br1 & $143.5(2)$ & $\mathrm{N} 22-\mathrm{Cu} 2-\mathrm{Br} 1$ & 104.1(1) \\
\hline $\mathrm{N} 11-\mathrm{Cu} 1-\mathrm{Br} 1$ & 109.8(1) & $\mathrm{N} 21-\mathrm{Cu} 2-\mathrm{N} 22$ & $83.8(2)$ \\
\hline $\mathrm{N} 12-\mathrm{Cu} 1-\mathrm{Br} 1$ & 104.9(1) & $\mathrm{C} 21-\mathrm{Cu} 2-\mathrm{N} 21$ & $84.6(2)$ \\
\hline $\mathrm{N} 11-\mathrm{Cu} 1-\mathrm{N} 12$ & $84.1(2)$ & $\mathrm{C} 21-\mathrm{Cu} 2-\mathrm{N} 22$ & $110.0(2)$ \\
\hline C11-Cu1-N11 & $86.2(2)$ & $\mathrm{C} 11-\mathrm{Cu} 3-\mathrm{C} 21$ & $159.5(2)$ \\
\hline
\end{tabular}

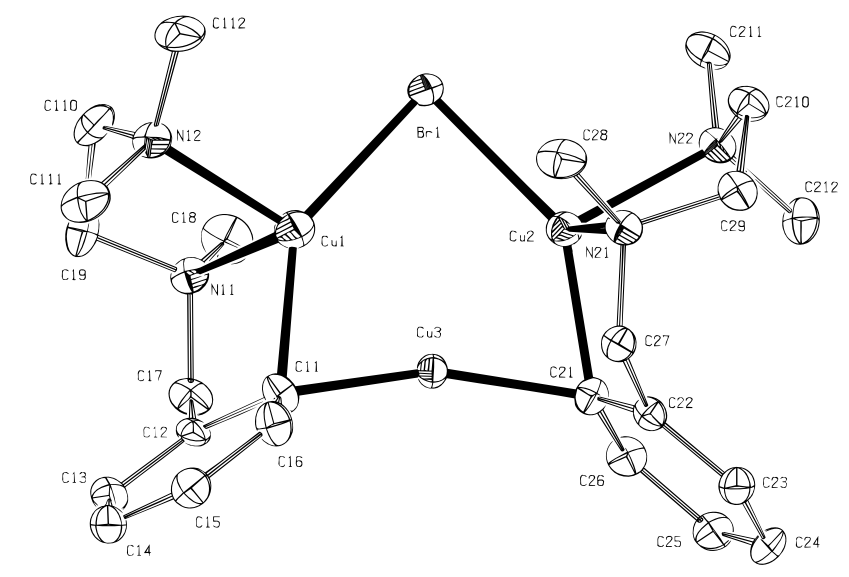

Figure 2. ORTEP drawing (thermal ellipsoids at $50 \%$ probability) of $\mathbf{6}$ (with the exclusion of the hydrogen atoms) with the atom-labeling scheme.

of products whose identity has not yet been established was obtained.

Structure of $\left[\mathrm{Cu}_{3} \mathrm{BrR}_{2}\right](6)$ in the Solid State. ${ }^{14}$ The molecular structure of $\mathbf{6}$ was established by X-ray diffraction techniques, and selected geometrical details are listed in Table 2.

Complex 6 (Figure 2) is a trinuclear copper aggregate of two arylcopper entities and one copper bromide unit. In the structure of $\mathbf{6}$ the copper atoms form an isosceles triangle and the two aryl ligands each bridge two copper atoms (Cu3, Cu1 and $\mathrm{Cu} 3, \mathrm{Cu} 2$ ). A bromide anion completes the structure by bridging copper atoms $\mathrm{Cu} 1$ and $\mathrm{Cu} 2\left(\angle \mathrm{Cu} 1-\mathrm{Br} 1-\mathrm{Cu} 2=85.75(3)^{\circ}\right)$. The ortho trimethylethylenediamine substituents of the aryl ligands each coordinate to one copper atom (Cu1 or $\mathrm{Cu} 2$ ) with both nitrogen atoms such that these centers acquire a distorted-tetrahedral geometry $(\angle \mathrm{N} 11-\mathrm{Cu} 1-\mathrm{N} 12$ and $\angle \mathrm{N} 21-\mathrm{Cu} 2-\mathrm{N} 22$ are $84.1(2)$ and $83.8(2)^{\circ}$, respectively); the copper-nitrogen distances Cu1-N11, Cu1-N12, Cu2-N21, and Cu2-N22 are 2.224(5), 2.158(5), 2.271(4), and 2.169(5) $\AA$, respectively. The third copper atom Cu3 is only bonded to the $\mu-\mathrm{C}_{\text {ipso }}($ aryl) atoms, and its coordination geometry deviates from linearity by ca. $20^{\circ}$ $\left(\angle \mathrm{C} 11-\mathrm{Cu} 3-\mathrm{C} 21=159.5(2)^{\circ}\right)$. The Cu-C-Cu angles associated with the bridging aryl ligands in $\mathbf{6}$ are, at $72.6(2)^{\circ}$, comparable to those in 3.

The $\mathrm{Cu}-\mathrm{C}$ distances involving the four-coordinated copper atoms in $\mathbf{6}$ (Cu1-C11 and Cu2-C21) are 2.108- 
(5) and 2.081(5) $\AA$ and are comparable to those in 3. However, within the "linear" C11-Cu3-C21 array in 6 the $\mathrm{Cu}-\mathrm{C}$ distances of 1.956(6) and 1.978(5) $\AA$ are significantly shorter, although they are longer than corresponding distances reported for diarylcuprate structures: e.g. 1.93(1) $\AA$ in $\left[\mathrm{CuPh}_{2}\right]^{-}, 16$ 1.915(9) $\AA$ in $\left[\mathrm{CuMes}_{2}\right]^{-}, 17$ and 1.936(3), 1.948(3) $\AA$ in $\left[\mathrm{Li}_{2} \mathrm{Cu}_{2}\left(\mathrm{C}_{6} \mathrm{H}_{4^{-}}\right.\right.$ $\left.\left.\mathrm{CH}_{2} \mathrm{NMe}_{2}-2\right)_{4}\right]^{18}$

Preparation of a Mixed 2:2 NaphthylcopperCopper Bromide $\left[\mathrm{Cu}_{4} \mathrm{Br}_{2} \mathbf{R}_{2}\right]$ Aggregate (10). Reaction of 1-bromo-2-(((2-(dimethyldiamino)ethyl)methylamino)methyl)naphthal ene with a stoichiometric amount based on lithium of n-BuLi or 2 equiv of t-BuLi using pentane as a solvent affords the corresponding naphthyllithium compound [ $\mathrm{Li}\left\{1-\mathrm{C}_{10} \mathrm{H}_{6}\left(\mathrm{CH}_{2} \mathrm{~N}(\mathrm{Me}) \mathrm{CH}_{2} \mathrm{CH}_{2^{-}}\right.\right.$ $\mathrm{NMe}_{2}$ )-2\} ] $]_{n}(9 a)$ (eq 4a), which has been isolated in 60$80 \%$ yield. Interestingly, when the reaction with $n-B u L i$ is performed in $\mathrm{Et}_{2} \mathrm{O}$ at $25{ }^{\circ} \mathrm{C}$, besides 9a significant amounts ( $\pm 20 \%$ ) of the organic coupling product 1-nBu- $\mathrm{C}_{10} \mathrm{H}_{6}\left(\mathrm{CH}_{2} \mathrm{~N}(\mathrm{Me}) \mathrm{CH}_{2} \mathrm{CH}_{2} \mathrm{NMe}_{2}\right)-2(\mathbf{9 b})$ are formed (eq $4 \mathrm{~b})$. This was shown by hydrolysis of a reaction mixture prepared in $\mathrm{Et}_{2} \mathrm{O}$, followed by GCMS and NMR analyses. ${ }^{19}$
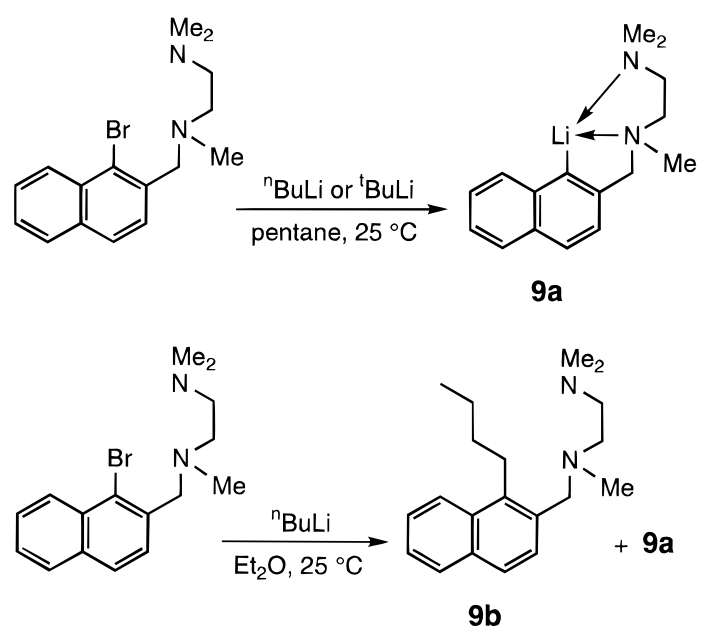

Compound 9a is an off-white pyrophoric solid, which is soluble in THF, benzene, and toluene and insoluble in pentane and hexane. NMR studies on 9a in benzene$\mathrm{d}_{6}$ and toluene- $\mathrm{d}_{8}$ indicate that the ortho trimethylethylenediamine substituents are coordinated to lithium. On the basis of analogy and similarity of the NMR data with those of the related substituted phenyllithium complex [ $\left.\mathrm{Li}_{2}\left\{\mathrm{C}_{6} \mathrm{H}_{4}\left(\mathrm{CH}_{2} \mathrm{~N}(\mathrm{Me}) \mathrm{CH}_{2} \mathrm{CH}_{2} \mathrm{NMe}_{2}\right)-2\right\}_{2}\right]$ (5), for which the structure in the solid state is known, ${ }^{15}$ we believe that $9 a$ is dimeric in solution and that both

(16) Hope, H.; Olmstead, M. M.; Power, P. P.; Sandell, J .; Xu, X. J . Am. Chem. Soc. 1985, 107, 4337-4338.

(17) Leoni, P.; Pasquali, M.; Ghilardi, C. A. J . Chem. Soc., Chem. Commun. 1983, 240-241.

(18) $\left[\mathrm{Li}_{2} \mathrm{Cu}_{2}(\operatorname{aryl})_{4}\right]:$ (a) van Koten, G.; Noltes, J . G. J . Am. Chem. Soc. 1979, 101, 6593-6599. (b) van Koten, G.; Noltes, J. G. J. Organomet. Chem. 1979, 171, C39-C43. (c) van Koten, G.; J astrzebski, J .T. B. H.; Muller, F.; Stam, C. H. J . Am. Chem. Soc. 1985, 107, 697698. (d) van Koten, G.; J astrzebski, J . T. B. H.; Stam, C. H.; Brevard, C. In Biological \& Inorganic Copper Chemistry; Karlin, K. D., Zubieta,

J ., Eds.; Adenine Press: Guilderland, NY, 1985; pp 267-285.

(19) Note that in a noncoordinating solvent naphthyl-butyl crosscoupling, i.e the formation of $\mathbf{9 b}$, does not occur. The formation of products analogous to $9 \mathbf{b}$ has recently been reported in the reaction of 2-bromo-1,3-xylyl-18-crown-5 with ${ }^{\mathrm{n}} \mathrm{BuLi}$ in THF at -10 to $0{ }^{\circ} \mathrm{C}$. When the reaction was carried out at $-78^{\circ} \mathrm{C}$, exclusive $\mathrm{Li}-\mathrm{Br}$ exchange takes place; see: J ohnson, S. E.; Knobler, C. B. Organometallics 1994, 13, 4928-4938.

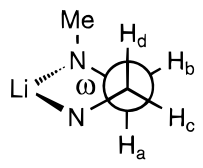

$\lambda$

$$
\mathrm{N}=\mathrm{NMe}_{2} ; \stackrel{\mathrm{Me}}{\mathrm{N}}=\mathrm{C}_{10} \mathrm{H}_{6} \mathrm{CH}_{2} \mathrm{~N}(\mathrm{Me}) \mathrm{CH}_{2} \mathrm{CH}_{2}
$$

Figure 3. $\lambda$ and $\delta$ conformations of $\left[\mathrm{Li}\left\{1-\mathrm{C}_{10} \mathrm{H}_{6}\left(\mathrm{CH}_{2} \mathrm{~N}\right.\right.\right.$ (Me) $\mathrm{CH}_{2} \mathrm{CH}_{2} \mathrm{NMe}_{2}$ )-2\}] (9a).

nitrogen atoms of each ortho trimethylethylenediamine substituent are coordinated to one Li atom. ${ }^{15}$ A Karplus analysis ${ }^{20}$ of the vicinal proton-proton coupling constants within the $\mathrm{NCH}_{2} \mathrm{CH}_{2} \mathrm{~N}$ multiplets indicates that the NCCN chelate is predominantly $(94 \pm 2 \%)$ in a $\lambda$ conformation (Figure 3 ) with a $\mathrm{N}-\mathrm{C}-\mathrm{C}-\mathrm{N}$ torsion angle $\omega$ of $60 \pm 2^{\circ}$. This is in good agreement with both the ring conformation and the $\mathrm{N}-\mathrm{C}-\mathrm{C}-\mathrm{N}$ torsion angle of $59.1(8)^{\circ}$ found in the solid-state structure of 5.15

Reaction of 2 equiv (based on $\mathrm{Li}$ ) of [ $\mathrm{Li}\left\{1-\mathrm{C}_{10} \mathrm{H}_{6}-\right.$ $\left.\left.\left(\mathrm{CH}_{2} \mathrm{~N}(\mathrm{Me}) \mathrm{CH}_{2} \mathrm{CH}_{2} \mathrm{NMe}_{2}\right)-2\right\}\right]$ (9a) with 4 equiv of copper(I) bromide affords al most quantitatively the mixed 2:2 naphthylcopper-copper bromide aggregate $\left[\mathrm{Cu}_{4}-\right.$ $\left.\mathrm{Br}_{2}\left\{1-\mathrm{C}_{10} \mathrm{H}_{6}\left(\mathrm{CH}_{2} \mathrm{~N}(\mathrm{Me}) \mathrm{CH}_{2} \mathrm{CH}_{2} \mathrm{NMe}_{2}\right)-2\right\}_{2}\right]$ (10) (eq 5). The use of less $\mathrm{CuBr}$ still leads to product $\mathbf{1 0}$ (see Experimental Section), and in the course of this study we were not able to isolate a mixed 2:1 naphthylcoppercopper bromide aggregate $\left[\mathrm{Cu}_{3} \mathrm{R}_{2} \mathrm{Br}\right]$ similar to $\mathbf{6}$.

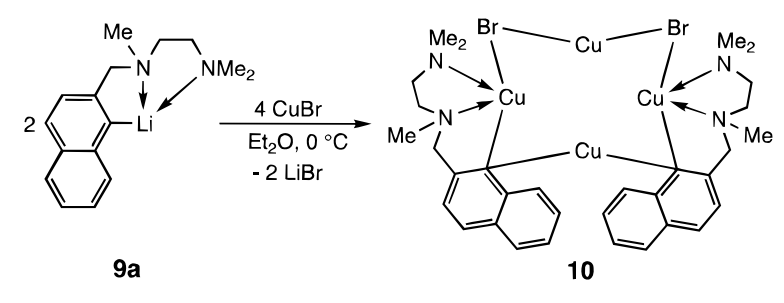

Complex $\mathbf{1 0}$ has been isolated in good yield as brownish yellow crystals which are less readily hydrolyzed or oxidized than $\mathbf{3}, \mathbf{6}$, and $\mathbf{7}$. Like the aggregates $\mathbf{6}$ and $\mathbf{7}$, the mixed 2:2 aggregate $\mathbf{1 0}$ is readily soluble in $\mathrm{Et}_{2} \mathrm{O}$, $\mathrm{THF}$, benzene, and toluene and is insoluble in pentane and hexane. Solutions of $\mathbf{1 0}$ in benzene or toluene turn bluish green upon exposure to air within $30 \mathrm{~min}$.

Structure of the 2:2 Naphthylcopper-Copper Bromide Aggregate $\left[\mathrm{Cu}_{4} \mathrm{Br}_{2} \mathrm{R}_{2}\right]$ (10) in the Solid State. The molecular structure of $\mathbf{1 0}$ was established by X-ray diffraction techniques, and selected geometrical details are listed in Table 3.

Aggregate $\mathbf{1 0}$ is a tetranuclear copper species of two 1-naphthylcopper molecules with 2 equiv of copper bromide (Figure 4). In this aggregate the copper atoms are positioned in a planar diamond-shaped array (largest deviation is 0.012(1) $\AA$ for Cu3) with the $\mathrm{Br}$ and $\mu-\mathrm{C}_{\text {ipso }}$ (naphthyl) atoms alternating above and below this plane. The two 1-naphthyl ligands bridge two copper atoms (Cu3, $\mathrm{Cu} 1$ and $\mathrm{Cu} 3, \mathrm{Cu} 2)$, while the two $\mathrm{Br}$ atoms each bridge one of the copper atom pairs $\mathrm{Cu} 4, \mathrm{Cu}$ and Cu4, Cu2. The trimethylethylenediamine substituent

(20) Karplus equations: $\mathrm{n}_{\lambda}=\left[\mathrm{X} \cos ^{2} \omega-\cos ^{2}(120-\omega)\right] /\left[\alpha \cos ^{2}(120\right.$ $\left.+\omega)-\cos ^{2}(120-\omega)\right] ; \mathrm{n}_{\delta}=\left[\mathrm{Y} \cos ^{2} \omega-\alpha \cos ^{2}(120+\omega)\right] /\left[\cos ^{2}(120-\omega)\right.$ $\left.-\alpha \cos ^{2}(120+\omega)\right] ; \mathrm{n}_{\lambda}+\mathrm{n}_{\delta}=1 . \mathrm{n}_{\lambda}\left(\mathrm{n}_{\delta}\right)$ is the mole fraction of the $\lambda(\delta)$ conformation, $X=J_{a, d} / J_{a, c}$, and $Y=J_{b, d} / J_{a, c}$. A value of 1.208 was previously determined for $\alpha$. 
Table 3. Selected Geometrical Details of $\left[\mathrm{Cu}_{4} \mathrm{Br}_{2}\left\{1-\mathrm{C}_{10} \mathrm{H}_{6}\left(\mathrm{CH}_{2} \mathrm{~N}(\mathrm{Me}) \mathrm{CH}_{2} \mathrm{CH}_{2} \mathrm{NMe}_{2}\right)-2\right\}_{2}\right] \cdot \mathrm{C}_{7} \mathrm{H}_{8}$ $\left(\mathbf{1 0} \cdot \mathrm{C}_{7} \mathrm{H}_{8}\right)^{\mathrm{a}}$

\begin{tabular}{|c|c|c|c|}
\hline \multicolumn{4}{|c|}{ Bond Distances $(\AA)$} \\
\hline Cu1-C1 & $2.032(8)$ & Cu1-Br1 & $2.458(1)$ \\
\hline $\mathrm{Cu} 3-\mathrm{C} 1$ & $1.986(8)$ & $\mathrm{Cu} 2-\mathrm{Br} 2$ & $2.479(1)$ \\
\hline Cu3-C21 & $1.974(8)$ & Cu4-Brl & $2.289(1)$ \\
\hline $\mathrm{Cu} 2-\mathrm{C} 21$ & $2.034(9)$ & $\mathrm{Cu} 4-\mathrm{Br} 2$ & $2.282(2)$ \\
\hline Cul-N1 & $2.235(8)$ & Cu1...cu3 & $2.408(1)$ \\
\hline Cu1-N2 & $2.140(8)$ & Cu2 $\cdots$ cu3 & $2.440(2)$ \\
\hline Cu2-N3 & $2.254(7)$ & Cu3 $\cdots$ Cu 4 & $2.520(1)$ \\
\hline $\mathrm{Cu} 2-\mathrm{N} 4$ & $2.167(6)$ & Cu1...Cu2 & $4.375(2)$ \\
\hline \multicolumn{4}{|c|}{ Bond Angles (deg) } \\
\hline Cu1-C1-Cu3 & 73.6(3) & C1-Cu1-Br1 & $151.2(2)$ \\
\hline $\mathrm{Cu} 2-\mathrm{C} 21-\mathrm{Cu} 3$ & $75.0(3)$ & $\mathrm{C} 21-\mathrm{Cu} 2-\mathrm{Br} 2$ & $151.9(2)$ \\
\hline Cu1-Br1-Cu4 & $67.60(4)$ & C1-Cu3-C21 & $142.4(3)$ \\
\hline Cu2-Br2-Cu4 & $67.00(4)$ & $\mathrm{Br} 1-\mathrm{Cu} 4-\mathrm{Br} 2$ & $155.32(6)$ \\
\hline
\end{tabular}

a The estimated standard deviations of the last significant digits are shown in parentheses.

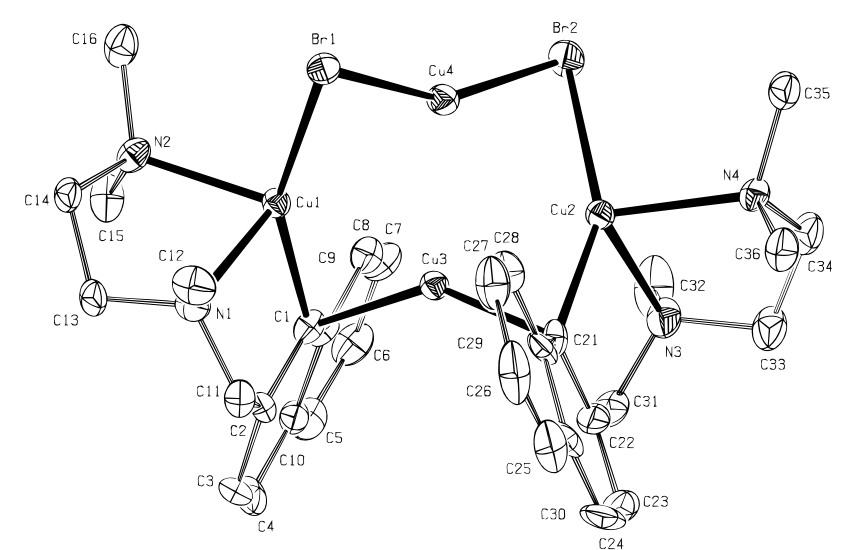

Figure 4. ORTEP drawing (thermal ellipsoids at $30 \%$ probability) of $\mathbf{1 0} \cdot \mathrm{C}_{7} \mathrm{H}_{8}$ (with the exclusion of the hydrogen atoms and the toluene solvate molecule) with the atomlabeling scheme.

of each naphthyl ligand coordinates with both nitrogen atoms to one copper atom, resulting in a distorted tetrahedral geometry of the copper atoms $\mathrm{Cu} 1$ and $\mathrm{Cu} 2$ (N1-Cu1-N2 and N3-Cu2-N4 are 85.1(3) and 83.2$(3)^{\circ}$, respectively). The two other copper atoms tend to a linear geometry, with Cu3 bonded only to the $\mu-\mathrm{C}_{\text {ipso- }}$ (1-naphthyl) atoms $\left(\angle \mathrm{C} 1-\mathrm{Cu} 3-\mathrm{C} 21=142.4(3)^{\circ}\right)$ and Cu4 bonded only to the $\mathrm{Br}$ atoms $(\angle \mathrm{Br} 1-\mathrm{Cu} 4-\mathrm{Br} 2=$ $\left.155.32(6)^{\circ}\right)$. In $\mathbf{1 0}$ the $\mathrm{Cu}-\mathrm{C}-\mathrm{Cu}$ angles of the bridging 1-naphthyl ligands $\mathrm{Cu} 1-\mathrm{C} 1-\mathrm{Cu} 3$ and $\mathrm{Cu} 2-\mathrm{C} 21-\mathrm{Cu} 3$ are $73.6(3)$ and $75.0(3)^{\circ}$, respectively. Thus, the naphthyl anion results in a two-el ectron-three-center (2e3c) type of bonding with $\mathrm{Cu}-\mathrm{C}-\mathrm{Cu}$ angles somewhat larger than in either $3\left(71.35(8)\right.$ and $\left.70.74(7)^{\circ}\right)$ or 6 $\left(72.6(2)^{\circ}\right)$. The halide bridges in 10, Cu1-Br1-Cu4 and Cu2-Br2-Cu4, have surprisingly acute angles of 67.60(4) and $67.00(4)^{\circ}$ that are about $15^{\circ}$ more acute than the corresponding angle in $\mathbf{6}$. However, these are not the most acute angles reported for a $\mathrm{Cu}-\mathrm{Br}-\mathrm{Cu}$ bridge: in the tetranuclear 2:2 aryl copper-copper bromide aggregate $\left[\mathrm{Cu}_{4} \mathrm{Br}_{2}\left\{\mathrm{C}_{6} \mathrm{H}_{3}\left(\mathrm{CH}_{2} \mathrm{NMe}_{2}\right)_{2}-2,6\right\}_{2}\right]$ the $\mathrm{Cu}-\mathrm{Br}-\mathrm{Cu}$ angles are 59.85(8) and 70.7(1) ${ }^{\circ}{ }^{1}$ The acute $\mathrm{Cu}-\mathrm{Br}-\mathrm{Cu}$ angles found in $\mathbf{6}$ and $\mathbf{1 0}$ and other aggregates ${ }^{1,3,4}$ can be described by the involvement of a $\mathrm{2e}-3 \mathrm{c}$ type of copper halide bonding (like that for $\mathrm{Cu}-$ $\mathrm{C}-\mathrm{Cu}$ bonding), although el ectrostatic bonding interactions cannot be excluded. Computational studies are clearly required to shed further light on the origin of these acute angles.
Selective Biaryl and Binaphthyl Formation from 6 and 10. When solutions of 6 in benzene or toluene are heated to temperatures above $55^{\circ} \mathrm{C}$, clean and quantitative formation of biaryl $\mathbf{8}$ occurs (eq 6). Simul-

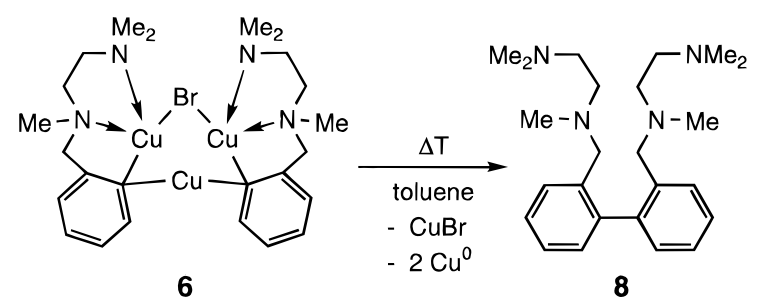

taneously, the reaction mixture turns into a brown suspension due to the formation of metallic copper. This thermal decomposition is complete within $15 \mathrm{~min}\left({ }^{1} \mathrm{H}\right.$ NMR), and a standard organic workup procedure affords biaryl $\mathbf{8}$ in moderate yields. The isolation of pure $\mathbf{8}$ is in particular made difficult by the formation of coordination complexes of the biaryl with the eliminated copper species (i.e., $\mathrm{CuBr}$ and $\left.\mathrm{Cu}^{0}\right) .{ }^{21 a}$

The ${ }^{1} \mathrm{H}$ NMR spectrum of $\mathbf{8}$ comprises well-defined and sharp signals, and since the benzylic protons appear as an $A B$ pattern with doublets at 3.25 and $3.41 \mathrm{ppm}$ ( ${ }^{\mathrm{J}}=14 \mathrm{~Hz}$ ), we conclude that there is a blocked rotation of the aryl rings with respect to each other.

Similarly, thermal decomposition of the mixed naphthylcopper-copper bromide aggregate $\mathbf{1 0}$ affords binaphthyl $\mathbf{1 1}$ (eq 7). In this case the yield of biaryl

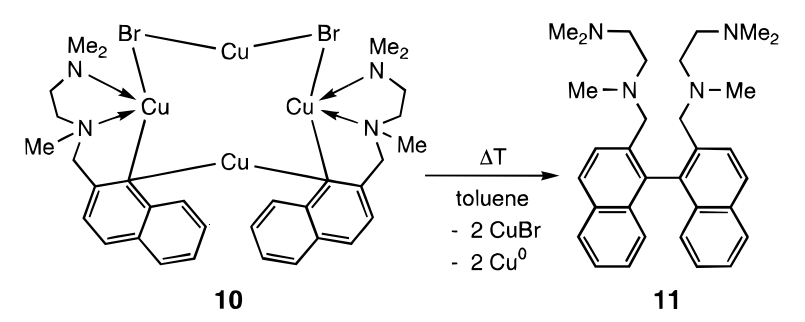

product $\mathbf{1 1}$ is moderate and does not exceed $42 \%$, even after $\mathbf{1 0}$ has been heated at reflux in toluene $\left(110{ }^{\circ} \mathrm{C}\right)$ for 1 week. ${ }^{22}$ A standard organic workup procedure of the reaction mixture from this experiment afforded only binaphthyl 11 and $\mathrm{C}_{10} \mathrm{H}_{7}\left(\mathrm{CH}_{2} \mathrm{~N}(\mathrm{Me}) \mathrm{CH}_{2} \mathrm{CH}_{2} \mathrm{NMe}_{2}\right)-2$, which results from hydrolysis of the 1-naphthyl ligand.

A preliminary conclusion is that the thermal reaction of $\mathbf{1 0}$ stops halfway, most probably because of the formation of a stable $\mathrm{Cu}^{\prime} \mathrm{Cu}^{0}$ species, ${ }^{22}$ from which apparently facile biaryl formation cannot occur. A reason for the different outcomes of the thermal reactions of $\mathbf{6}$ and $\mathbf{1 0}$ could be the steric influence of the phenyl vs the naphthyl ligands or the stability of intermediates formed during these reactions.

The ${ }^{1} \mathrm{H}$ NMR spectrum of binaphthyl $\mathbf{1 1}$ comprises well-defined and sharp signals with the benzylic protons affording a well-resolved $A B$ pattern of two doublets at 3.19 and $3.50 \mathrm{ppm}$ with a ${ }^{2} \mathrm{j}$ value of $14 \mathrm{~Hz}$; this is

(21) (a) van Koten, G.; J astrzebski, J . T. B. H.; Noltes, J . G. I norg. Chim. Acta 1977, 21, L9-L11. (b) van Koten, G.; J astrzebski, J . T. B. H.; Noltes, J . G. J . Org. Chem. 1977, 42, 2047-2053.

(22) The possibility that the reaction stops at the stage of thermally very stable mixed-valence naphthylcopper $(I)$-copper $(0)$ bromide species is presently under investigation. Cf.: Cairncross, A.; Omura, H.; Sheppard, W. A. J . Am. Chem. Soc. 1971, 93, 248-249. The fact that after hydrolysis substantial amounts of $\mathrm{C}_{10} \mathrm{H}_{7}\left(\mathrm{CH}_{2} \mathrm{~N}(\mathrm{Me}) \mathrm{CH}_{2} \mathrm{CH}_{2^{-}}\right.$ $\mathrm{NMe}_{2}$ )-2 are isolated is in accord with the presence of a $\mathrm{C}_{\text {ipso }}$ (naphthyl)$\mathrm{Cu}$ bond in the mixed-valence species. 


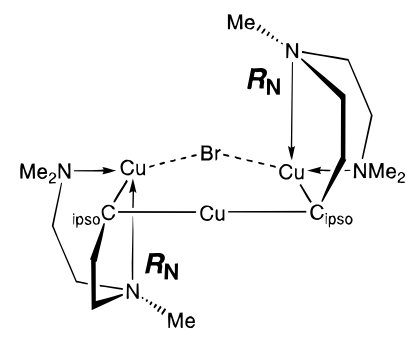

a

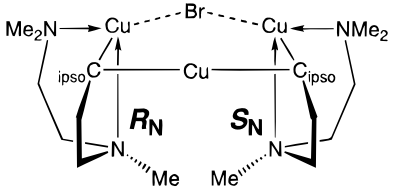

b
Figure 5. Symmetry in the two diastereoisomers of $\mathbf{6}$ (phenyl rings omitted for clarity): (a) $R_{N} R_{N}$ isomer with $\mathrm{C}_{2}$ symmetry corresponding to the solid-state structure of 6; (b) $R_{N} S_{N}$ isomer with mirror plane symmetry.

consistent with blocked rotation of the naphthyl rings relative to each other.

Structures of 6, 7, and 10 in Solution: Stereochemical Aspects. The ${ }^{1} \mathrm{H}$ NMR spectra of aggregates 6, 7, and $\mathbf{1 0}$ are temperature dependent and provide interesting insights into the structures of these species in solution. In all these complexes the patterns and behavior of the resonances of the $\mathrm{CH}_{2} \mathrm{~N}(\mathrm{Me}) \mathrm{CH}_{2} \mathrm{CH}_{2-}$ $\mathrm{NMe}_{2}$ substituents indicate that there is fluxionality due to processes involving intramolecular $\mathrm{Cu}-\mathrm{N}$ dissociation/association. This was to be expected, since ${ }^{1} \mathrm{H}$ and ${ }^{13} \mathrm{C}$ NMR investigations on $\left[\mathrm{Cu}_{4}\left\{\mathrm{C}_{6} \mathrm{H}_{4} \mathrm{CH}_{2} \mathrm{NMe}_{2}-2\right\}_{4}\right]$ (3) and the related $\left.\left[\mathrm{Cu}_{4}\left\{\mathrm{C}_{6} \mathrm{H}_{4}(\mathrm{R})-\mathrm{CH}(\mathrm{Me}) \mathrm{NMe}_{2}\right)-2\right\}_{4}\right]$ have already shown the occurrence of intra- and intermolecular fluxional processes. ${ }^{23}$

The low-temperature $(263 \mathrm{~K})$ spectrum of $\left[\mathrm{Cu}_{3} \mathrm{Br}\right.$ $\left.\left\{\mathrm{C}_{6} \mathrm{H}_{4}\left(\mathrm{CH}_{2} \mathrm{~N}(\mathrm{Me}) \mathrm{CH}_{2} \mathrm{CH}_{2} \mathrm{NMe}_{2}\right)-2\right\}_{2}\right]$ (6) in toluene-d consists of two equally intense patterns for two inequival ent $\mathrm{C}_{6} \mathrm{H}_{4}\left(\mathrm{CH}_{2} \mathrm{~N}(\mathrm{Me}) \mathrm{CH}_{2} \mathrm{CH}_{2} \mathrm{NMe}_{2}\right)-2$ ligands. This is exemplified by two doublets from the aromatic proton ortho to copper at 8.43 and $8.28 \mathrm{ppm}$ and two doublets from the aromatic proton ortho to the $\mathrm{CH}_{2} \mathrm{~N}(\mathrm{Me}) \mathrm{CH}_{2-}$ $\mathrm{CH}_{2} \mathrm{NMe}_{2}$ substituent at 6.84 and $6.65 \mathrm{ppm}$. Moreover, there are two sets of benzylic proton signals: i.e, one $\mathrm{CH}_{2}$ group affords a broad singlet at $3.77 \mathrm{ppm}$, with the other affording an $\mathrm{AB}$ pattern with doublets at 3.8 and $3.39 \mathrm{ppm}$. The signals of the $\mathrm{N}(\mathrm{Me}) \mathrm{CH}_{2} \mathrm{CH}_{2} \mathrm{NMe}_{2}$ groups fall between 0.8 and 2.9 ppm as broad and complex resonances. Increasing the temperature to 297 $\mathrm{K}$ leads to coalescence of both the doublets at 8.43 and $8.28 \mathrm{ppm}$ as well as the doublets at 6.84 and $6.65 \mathrm{ppm}$. These data are consistent with the existence of two species at low temperature that interconvert at higher temperatures. Because of the biaryl formation that occurs in the case of $\mathbf{6}$ above $55^{\circ} \mathrm{C}$, its fast-exchange spectrum could not be obtained.

Since the $\mathrm{CH}_{2} \mathrm{~N}(\mathrm{Me}) \mathrm{CH}_{2} \mathrm{CH}_{2}$ nitrogen (inner $\mathrm{N}$ ) atom is stereogenic when coordinated to copper, and since aggregate 6 contains two aryl ligands, it is likely that the two species observed are two diastereoi somers. The species with $R_{N} R_{N}$ (or $S_{N} S_{N}$ ) chirality (Figure $5 a$ ) contains a $C_{2}$ axis and affords one ligand pattern; the other with $\mathrm{R}_{\mathrm{N}} \mathrm{S}_{\mathrm{N}}$ chirality possesses a mirror plane (cf. the stereochemical analysis of $\left[\mathrm{Li}_{2}\left\{\mathrm{C}_{6} \mathrm{H}_{4}\left(\mathrm{CH}_{2} \mathrm{~N}(\mathrm{Me}) \mathrm{CH}_{2}-\right.\right.\right.$ $\mathrm{CH}_{2} \mathrm{NMe}_{2}$ )-2 $\}_{2}$ ] (5) in ref 27) (Figure 5b) and also affords one ligand pattern. It is very likely that the interconversion of these two diastereoisomers is an intramolecular process, ${ }^{23}$ for which it is essential that the inner

(23) van Koten, G.; J astrzebski, J . T. B. H. Tetrahedron 1989, 45, 569-578.
$\mathrm{N}-\mathrm{Cu}$ bond must be broken to achieve inversion of configuration of the inner $\mathrm{N}$ atom; i.e., $\mathrm{N}$-donor dissociation of both the $\mathrm{Me}_{2}$ group (outer $\mathrm{N}$ ) and the inner $\mathrm{N}$ must occur. Furthermore, after inversion of configuration at the inner $\mathrm{N}$ atom, it is also necessary for the aryl ring to rotate around the $\mathrm{Cu}-\mathrm{C} 2 \mathrm{e}-3 \mathrm{c}$ bond before both $\mathrm{N}$-donor atoms can recoordinate to $\mathrm{Cu}$. ${ }^{18 a}$

The ${ }^{1} \mathrm{H}$ NMR spectra of $\left[\mathrm{Cu}_{4} \mathrm{Br}_{2}\left\{\mathrm{C}_{6} \mathrm{H}_{4}\left(\mathrm{CH}_{2} \mathrm{~N}(\mathrm{Me}) \mathrm{CH}_{2-}\right.\right.\right.$ $\left.\left.\mathrm{CH}_{2} \mathrm{NMe}_{2}\right)_{-2}\right\}_{2}$ ] (7) show temperature-dependent behavior due to the presence of an equilibrium between two diastereoisomers anal ogous to that ascribed to complex 6. At $297 \mathrm{~K}$ in toluene- $\mathrm{d}_{8}$, the major diastereoisomer affords aromatic protons ortho to copper and ortho to the $\mathrm{CH}_{2} \mathrm{~N}(\mathrm{Me}) \mathrm{CH}_{2} \mathrm{CH}_{2} \mathrm{NMe}_{2}$ substituent as broadened singlets at 8.30 and 6.73 ppm, respectively. When this solution is cooled, there is decoal escence of these signals and at $263 \mathrm{~K}$ one sees two doublets from the former at 8.42 and $8.28 \mathrm{ppm}$ and two doublets from the latter at 6.85 and $6.63 \mathrm{ppm}$. Another clear change is found for the inner NMe group that affords at $297 \mathrm{~K}$ a singlet at $2.46 \mathrm{ppm}$ and that at $273 \mathrm{~K}$ has decoalesced into two singlets at 2.51 and $2.40 \mathrm{ppm}$. The second, minor, diastereoisomer is characterized by a doublet at 8.57 ppm, and the single ligand pattern observed is virtually temperature independent in the range 233-297 K. However, with decreasing temperature the intensity of this pattern decreases relative to that of the major species. On the basis of the solid-state structure of $\mathbf{1 0}$, complex $\mathbf{7}$ is assumed to have a planar $\mathrm{Cu}_{4}$ array with $\mu-\mathrm{C}_{\mathrm{ipso}}(\mathrm{aryl})$ and $\mathrm{Br}$ alternating above and below this plane. The $\mathrm{R}_{\mathrm{N}} \mathrm{S}_{\mathrm{N}}$ diastereoi somer has no mi rror plane symmetry, and this (the major species in solution) affords two ligand patterns in a 1:1 ratio as opposed to only one ligand pattern in the case of 6 . The $R_{N} R_{N}$ $\left(S_{N} S_{N}\right)$ minor species has $C_{2}$ symmetry (in accord with the solid-state structure of $\mathbf{1 0}$ ) and consequently affords just one ligand pattern.

The slow-exchange ${ }^{1} \mathrm{H}$ NMR spectrum of naphthylcopper-copper bromide aggregate $\left[\mathrm{Cu}_{4} \mathrm{Br}_{2}\left\{1-\mathrm{C}_{10} \mathrm{H}_{6}\right.\right.$ $\left.\left.\left(\mathrm{CH}_{2} \mathrm{~N}(\mathrm{Me}) \mathrm{CH}_{2} \mathrm{CH}_{2} \mathrm{NMe}_{2}\right)-2\right\}_{2}\right](\mathbf{1 0})$ is al ready reached at room temperature $(297 \mathrm{~K})$ and consists of nicely resolved, although partially overlapping, multiplets for the naphthyl protons with the characteristic proton ortho to copper visible as a doublet at $9.38 \mathrm{ppm}$. Since the benzylic protons afford an $A B$ pattern (doublets at 2.94 and $2.44 \mathrm{ppm}$ ), one can conclude that the inner nitrogen atom is coordinated to copper; the NMe group affords a singlet at $2.33 \mathrm{ppm}$. The observation of two broad singlets for the $\mathrm{NMe}_{2}$ (outer $\mathrm{N}$ ) group at 2.08 and $0.61 \mathrm{ppm}$ indicates that this nitrogen atom is also coordinated to copper on the NMR time scale. The resonances of the $\mathrm{CH}_{2} \mathrm{CH}_{2}$ group, which are partially obscured by the low-field $\mathrm{NMe}_{2}$ singlet, occur as a set of slightly broadened multiplets between 2.0 and 0.8 ppm. This ligand pattern is assigned to the $R_{N} R_{N}$ $\left(\mathrm{S}_{\mathrm{N}} \mathrm{S}_{\mathrm{N}}\right.$ ) diastereoi somer (having $\mathrm{C}_{2}$ symmetry), which corresponds to the solid-state molecular structure. This slow-exchange spectrum of $\mathbf{1 0}$ also contains signals that originate from less than $10 \%$ of a second species, which may be the $\mathrm{R}_{N} \mathrm{~S}_{\mathrm{N}}$ diastereoi somer. However, due to severe overlap of its resonances with those of the major component its identity has not been elucidated. The two $\mathrm{NMe}_{2}$ singlets of the $\mathrm{R}_{N} \mathrm{R}_{N}\left(\mathrm{~S}_{N} \mathrm{~S}_{N}\right)$ diastereoisomer coalesce upon increasing the solution temperature, but because of the presence of underlying resonances an 


\section{Scheme 1. Cuprates and Mixed Aggregates in the Synthesis of Arylcopper Complexes}

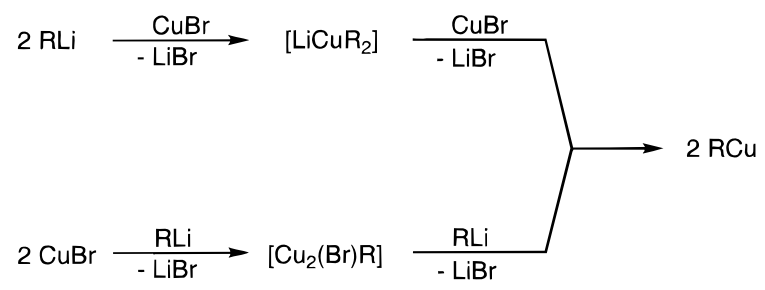

exact coal escence temperature (and thus $\Delta \mathrm{G}^{\ddagger}$ value for the $\mathrm{Cu}-\mathrm{N}$ dissociation/association process) was not determined.

\section{Discussion}

Syntheses. The synthesis of $\mathbf{3}, \mathbf{6}, \mathbf{7}$, and $\mathbf{1 0}$ is straightforward, and this is notable, since earlier syntheses of aryl coppers such as $\mathbf{3}$ using copper (I) bromide needed the development of special protocols, important parameters being the order of addition of the reagents, reaction temperature, reaction time, and sol vents. ${ }^{24} \mathrm{~F}$ or example, in the case of $\mathbf{3}$ it was reported that addition of copper bromide to a solution of organolithium reagent initially leads to the corresponding cuprate, while the reverse addition results in the formation of mixed organocopper-copper bromide aggregates (Scheme 1). Accordingly, the desired organocopper is accessible from either a cuprate or a mixed organocopper-copper bromide aggregate in subsequent reactions.

Thus, the successful isolation of a pure organocopper species depends on three factors: (a) the stability of both [ $\mathrm{CiCuR}_{2}$ ] and $\left[\mathrm{Cu}_{n+m} \mathrm{Br}_{n} \mathrm{R}_{m}\right.$ ], (b) the reactivity of [Li$\mathrm{CuR}_{2}$ ] toward copper bromide, and (c) the reactivity of (possibly aggregated) [LiR] toward mixed aggregates $\left[\mathrm{Cu}_{n+m} \mathrm{Br}_{n} \mathrm{R}_{m}\right]$. Depending on the stability and reactivity of $\left[\mathrm{LiCuR}_{2}\right]$ and $\left[\mathrm{Cu}_{n+m} \mathrm{Br}_{n} R_{m}\right]$, one can select the appropriate route for the synthesis of the desired organocopper complex. This principle is nicely illustrated in the reported synthesis of $\left[\mathrm{Cu}_{4}\left\{\mathrm{C}_{6} \mathrm{H}_{4}\left(\mathrm{CH}_{2}-\right.\right.\right.$ $\left.\left.\mathrm{NMe}_{2}\right)_{-2}\right\}_{4}$ ] (3), where addition of $\mathrm{CuBr}$ to the aryllithium reagent $\left[\mathrm{Li}\left\{\mathrm{C}_{6} \mathrm{H}_{4}\left(\mathrm{CH}_{2} \mathrm{NMe}_{2}-2\right)\right\}\right]$ affords the pure arylcopper species in $44 \%$ yield, while the reverse addition merely leads to decomposition. ${ }^{12 c, 24}$

The preparation of $\mathbf{3}$ presented in this study using the copper(I) arenethiolate $\left[\mathrm{Cu}_{3}\left(\mathrm{SC}_{6} \mathrm{H}_{4} \mathrm{NMe}_{2}-2\right)_{3}\right](\mathbf{2})^{10}$ does not suffer such problems; high yields of pure aryl copper $\mathbf{3}$ can be obtained by either adding copper arenethiolate $\mathbf{2}$ to a solution of organol ithium reagent $\mathbf{1}$ or vice versa, and decomposition is not observed. Moreover, the use of other copper(I) arenethiolate species such as $\left[\mathrm{Cu}_{3}\left(\mathrm{SC}_{6} \mathrm{H}_{4}\left(\mathrm{CH}_{2} \mathrm{NMe}_{2}\right)-2\right)_{3}\right]^{25}$ and $\left[\mathrm{Cu}_{9}(\mathrm{~S}-\right.$ 1- $\left.\left.\mathrm{C}_{10} \mathrm{H}_{6} \mathrm{NMe}_{2}-8\right)_{9}\right]^{10}$ is also feasible.

The fact that mixed arylcopper-copper halide aggregates can be inert toward an excess of organolithium reagents is nicely illustrated by the isolation of mixed aggregates 6 and 10, even when their syntheses are performed with a copper to lithium ratio of 1:1. This indicates that the mixed aggregates $\mathbf{6}$ and $\mathbf{1 0}$ and the corresponding organolithium aggregates are stable and can coexist in solution. Consequently, the use of dif-

(24) (a) van Koten, G.; Leusink, A. J .; Noltes, J . G. J . Organomet. Chem. 1975, 84, 117-127. (b) van Koten, G.; Noltes, J. G. J . Organomet. Chem. 1975, 84, 419-429.

(25) Knotter, D. M.; van Maanen, H. L.; Grove, D. M.; Spek, A. L.; van Koten, G. Inorg. Chem. 1991, 30, 3309-3317.

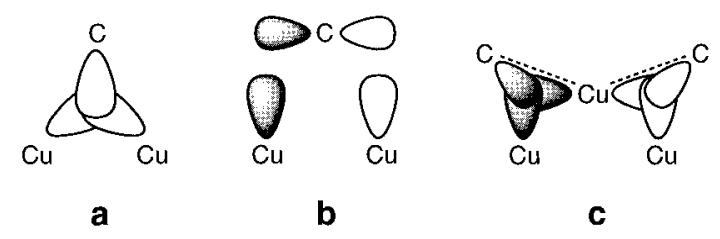

Figure 6. Representation of the two-electron three-center (2e-3c) $\mathrm{Cu}-\mathrm{C}($ aryl) bond.

ferent organolithium aggregates may lead to the formation of mixed organocopper aggregates (cf. the formation of the 4:2 $\left[\mathrm{Cu}_{6}(\mathrm{R})_{4}\left(\mathrm{R}^{\prime}\right)_{2}\right]$ aggregate in ref 8$)$. The latter species are directly relevant as model complexes that can be used to underline mechanistic proposals in the intraaggregate coupling reactions of aryl and alkynyl groups. $8 \mathrm{~b}$

Structures of Aggregates $3,136,7$, and 10. Complexes $\mathbf{6}, \mathbf{7}$, and $\mathbf{1 0}$ are examples of mixed organocopper-copper halide aggregates whose structural features combined with their reactivity (biaryl formation) allow us to formulate such species in terms of lower order cuprates. In these species, the nature of the bonding of the aryl ligand within the aggregate is important in determining their properties. In summary, the aryl ligands in 3, 6, and $\mathbf{1 0}$ each bridge two copper atoms and the corresponding $\mathrm{Cu}-\mathrm{C}-\mathrm{Cu}$ angles are acute (71.35(8) and 70.74(7) in 3, 72.6(2) in 6, and 73.6(3) and $75.0(3)^{\circ}$ in 10 ). These acute angles have been ascribed as the result of $2 \mathrm{e}-3 \mathrm{c}$ bonding of the aryl nucleus to two copper atoms (Figure $6 a, b) .8 c$

In more detail, Figure $6 a$ shows the most important orbital interaction for the $\mathrm{Cu}-\mathrm{C}-\mathrm{Cu}$ bridge bond, that is bonding not only between $\mathrm{C}$ and $\mathrm{Cu}$ but al so between the two $\mathrm{Cu}$ atoms. This orbital overlap does not influence the positioning of the aryl ring with respect to the $\mathrm{Cu} \cdots \mathrm{Cu}$ vector, and its symmetry allows rotation of the aryl ring in fluxional processes. Second, Figure $6 \mathrm{~b}$ displays a contribution that is bonding between $\mathrm{C}$ and $\mathrm{Cu}$ (donation from the filled $\pi$-aryl to $\mathrm{Cu}$ ) but is nonbonding between the two $\mathrm{Cu}$ atoms. The latter contribution is responsible for the commonly found orientation of bridging aryl and naphthyl systems perpendicular to the $\mathrm{Cu} \cdots \mathrm{Cu}$ vector. This orientation also theoretically allows a back-donating component in the $\mathrm{Cu}-\mathrm{C}$ bonding that comprises donation from a filled $\mathrm{Cu}$ orbital into an empty $\pi^{*}$-aryl (not shown). Preliminary calculations ${ }^{26}$ show that the LUMO in $\mathbf{6}$ has significant contributions from the two $\pi^{*}$ orbitals of both aryl $\mathrm{C}_{\text {ipso }}$ atoms and a $\mathrm{Cu}$ orbital with suitable symmetry.

On the basis of this model, one can understand why complexes such as $\mathbf{3 , 6}$, and $\mathbf{1 0}$ have structures with aryl rings positioned perpendicular with respect to the $\mathrm{Cu}$...$\mathrm{Cu}$ vector. This is also the orientation favored by (bulky) ortho substituents. The naphthylcopper compound $\mathbf{1 0}$ is significantly more (thermally) stable than 6 and 7. This can be attributed to the fact that the naphthyl anion is a better electron donor than the phenyl anion and, furthermore, to the presence of two bulky ortho substituents (i.e. (methylamino)methyl and stereochemically active $\mathrm{H}-8$ ) that prevent rotation of the aryl unit. The relatively good thermal stability we find for $\mathbf{3}$ and $\mathbf{1 0}$ is fully consistent with earlier

(26) CAChe scientific molecular modeling system, extended Hückel, basis set STO-3G using Alvarez collected parameters. 


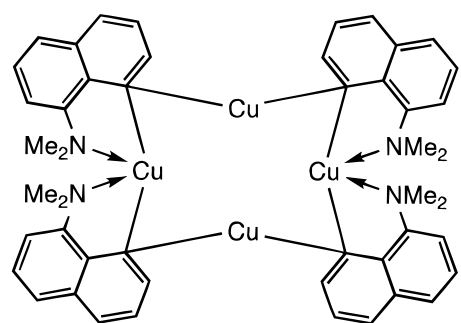

Figure 7. Schematic structure of tetranudear (8-(dimethylamino)-1-naphthyl)copper.

observations that the stability of arylcopper compounds increases with the introduction of substituents ortho to the $\mathrm{Cu}-\mathrm{C}$ bond. This stability increase was ascribed to an increasing participation of an orbital overlap such as that displayed in Figure $6 \mathrm{~b} .{ }^{21 b}$

Because the structure of complex 6 contains a twocoordinate copper atom with a close to linear geometry, it is tempting to interpret this $\mathrm{R}-\mathrm{Cu}-\mathrm{R}$ arrangement as representing a "lower order" homocuprate [CuR $\left.]_{2}\right]^{-}$ anion $\left(\mathrm{R}=\mathrm{C}_{6} \mathrm{H}_{4}\left(\mathrm{CH}_{2} \mathrm{~N}(\mathrm{Me}) \mathrm{CH}_{2} \mathrm{CH}_{2} \mathrm{NMe}_{2}\right)-2\right)$ combined with the dicopper bromide cation $\left[\mathrm{Cu}_{2} \mathrm{Br}\right]^{+}$. Complex 10 can be described similarly as the cuprate [CuR $]^{-}$ $\left(\mathrm{R}=1-\mathrm{C}_{10} \mathrm{H}_{6}\left(\mathrm{CH}_{2} \mathrm{~N}(\mathrm{Me}) \mathrm{CH}_{2} \mathrm{CH}_{2} \mathrm{NMe}_{2}\right)-2\right)$ stabilized by the tricopper dibromide cation $\left[\mathrm{Cu}_{3} \mathrm{Br}_{2}\right]^{+}$. Interestingly, complex 7, which is related to 6 by an extra $\mathrm{CuBr}$ unit, can be expected to contain a similar $\left[\mathrm{Cu}_{3} \mathrm{Br}_{2}\right]^{+}$cation and $\left.a \mathrm{CCuR}_{2}\right]^{-}$anion. The deviation from a linear geometry for the two-coordinate (sp-hybridized) copper atoms in $\mathbf{6}$ and $\mathbf{1 0}$ results from the $2 \mathrm{e}-3 \mathrm{c}$ bonding of the aryl (naphthyl) groups (Figure 6c). ${ }^{27}$ The description of these mixed arylcopper-copper bromide aggregates as cuprate species is substantiated not only by the shorter $\mathrm{Cu}-\mathrm{C}$ distances within the $\left[\mathrm{CuR}_{2}\right]^{-}$units as compared with the $\mathrm{Cu}$ (four coordinate)- $\mathrm{C}$ distances but, more importantly, also by the selective biaryl and binaphthyl formation found for 6, 7, and $\mathbf{1 0}$ at el evated temperatures. The $\left[\mathrm{Cu}_{n+1} \mathrm{Br}_{n}\right]^{+}$cations in these complexes are stabilized by bidentate coordination of the diamine substituents. It is likely in the case of $\mathbf{6}$ and $\mathbf{1 0}$ that this additional $\mathrm{Cu}-\mathrm{N}$ coordination stabilizes these novel aggregates in a thermodynamic sense with respect to other possible arylcopper-copper halide aggregates. However, it must be noted that in biaryl coupling reactions of arylcopper reagents species similar to $\mathbf{6}$ and $\mathbf{1 0}$ can be formed in equilibria and are the kinetically active species from which biaryl formation occurs.

Biaryl and Binaphthyl Formation. The selective biaryl and binaphthyl formation from the mixed arylcopper-copper bromide aggregates $\left[\mathrm{Cu}_{3} \mathrm{BrR}_{2}\right](\mathbf{6})$ and $\left[\mathrm{Cu}_{4} \mathrm{Br}_{2} \mathrm{R}_{2}\right](\mathbf{1 0})$ upon heating is remarkable, and it is tempting to correlate this directly to the structures of these aggregates in the solid state (videsupra) that we have established to be retained in solution. The tetranuclear naphthylcopper $\left[\mathrm{Cu}_{4}\left(1-\mathrm{C}_{10} \mathrm{H}_{6} \mathrm{NMe}_{2}-8\right)_{4}\right]$ (Figure 7), in which two "linear" $\mathrm{R}-\mathrm{Cu}-\mathrm{R}$ entities are present (i.e, this pure compound can be described as comprising two $\left[\mathrm{CuR}_{2}\right]^{-}$units stabilized by two four-coordinate $\mathrm{Cu}^{+}$ cations), shows binaphthyl formation upon reflux in mesitylene (the molar ratio $\mathrm{RR}: \mathrm{RH}$ is $1: 2$ after $2 \mathrm{~h}$ ). ${ }^{28}$

In contrast, tetranuclear and pentanuclear mixed arylcopper-copper bromide aggregates $\left[\mathrm{Cu}_{4} \mathrm{Br}_{2} \mathrm{R}_{2}\right](\mathrm{R}=$

(27) van Koten, G.; J astrzebski, J . T. B. H.; Noltes, J . G. Inorg. Chem. 1977, 16, 1782-1787.

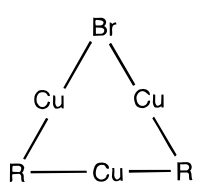

$\left[\mathrm{Cu}_{3}(\mathrm{Br}) \mathrm{R}_{2}\right]$

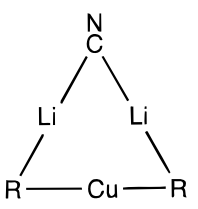

$\left[\mathrm{Li}_{2} \mathrm{Cu}(\mathrm{CN}) \mathrm{R}_{2}\right]$
Figure 8. Comparison of $\left[\mathrm{Cu}_{3} \mathrm{BrR}_{2}\right]$, eg. 6, with $\left[\mathrm{Li}{ }_{2} \mathrm{Cu}-\right.$ $\left.(\mathrm{CN}) \mathrm{R}_{2}\right]$.

$\left.\mathrm{C}_{6} \mathrm{H}_{3}\left(\mathrm{CH}_{2} \mathrm{NMe}_{2}\right)_{2}-2,6\right)^{1}$ and $\left[\mathrm{Cu}_{5} \mathrm{Br}_{3} \mathrm{R}_{2}\right]\left(\mathrm{R}=\mathrm{C}_{6} \mathrm{H}_{3}\left(\mathrm{CH}_{2} \mathrm{~N}-\right.\right.$ (Me) $\left.\left.\mathrm{CH}_{2} \mathrm{CH}_{2} \mathrm{NMe}_{2}\right)_{2}-2,6\right),{ }^{3}$ which have completely different structures (thelatter aggregate can be described as two $\left[\mathrm{Cu}_{2} \mathrm{R}\right]^{+}$entities stabilized by a $\left[\mathrm{CuBr}_{3}\right]^{2-}$ unit), have decomposition temperatures $\left(T_{\text {dec }} \gg 100^{\circ} \mathrm{C}\right)$ much higher than for complexes $\mathbf{6}$ and $\mathbf{1 0 .}$

Using these arguments, the thermal decomposition of $\left[\mathrm{Cu}_{4}\left(\mathrm{C}_{6} \mathrm{H}_{4} \mathrm{CH}_{2} \mathrm{NMe}_{2}-2\right)_{4}\right](3)$ in naphthalene at $165^{\circ} \mathrm{C}$, which leads to the biaryl (RR; $57 \%$ ) and the arene species ( $\mathrm{RH} ; 6 \%$ ) after $6 \mathrm{~h}$ (eq 8a), ${ }^{21}$ shows that the three-coordinate copper atoms in $\mathbf{3}$ are not fully equipped to result in facile biaryl formation. Treatment of $\mathbf{3}$ with cupric halides $\left(\mathrm{CuBr}_{2}, \mathrm{CuCl}_{2}\right)$ leads mainly to the formation of halogenated aromatic compounds (as a result of ligand transfer oxidation), ${ }^{29}$ while the corresponding biaryl is only obtained in a moderate yield of $37 \%{ }^{24}$ Higher (up to quantitative) yields of biaryl can be obtained by the use of copper (I) trifluoromethanesulfonate (CUOTf) in stoichiometric amounts in the case of ortho-amine-substituted arylcopper compounds, whereas quantitative biaryl formation can be achieved through the use of catalytic amounts of CuOTf when the arylcopper compound has no coordinating substituents (eq 8b). ${ }^{21}$

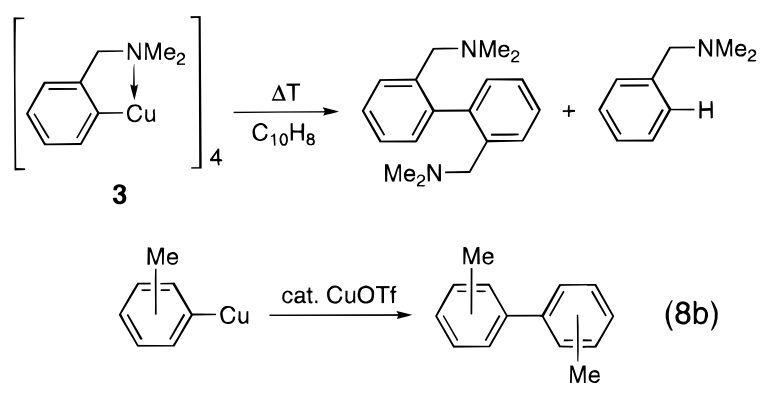

The stoichiometry and the structure of $\mathbf{6},\left[\mathrm{Cu}_{3} \mathrm{BrR}_{2}\right]$, can be seen to bear analogy to the heavily debated "higher order" cyanocuprates $\left[\mathrm{Li}_{2} \mathrm{Cu}(\mathrm{CN}) \mathrm{R}_{2}\right]$ (Figure 8) ${ }^{30-32}$ and their presumably related variants $\left[\mathrm{Li}_{2} \mathrm{CuR}_{3}\right]$. Studies on $\left[\mathrm{Li}_{2} \mathrm{CuMe}_{3}\right]$ indicate that this species is

(28) Wehman, E.; van Koten, G.; Knotter, D. M.; Spelten, H.; Heijdenrijk, D.; Mak, A. N. S.; Stam, C. H. J . Organomet. Chem. 1987, 325, 293-309.

(29) Kochi, J . K. Organometallic Mechanisms and Catalysis; Academic Press: New York, 1978.

(30) (a) Lipshutz, B. H.; Siegmann, K.; Garcia, E. J . Am. Chem. Soc. 1991, 113, 8161-8162. (b) Lipshutz, B. H.; Siegmann, K.; Garcia, E. Tetrahedron 1992, 48, 2579-2588. (c) Lipshutz, B. H.; J ames, B. J . Org. Chem. 1994, 59, 7585-7587. (d) Lipshutz, B. H.; Kayser, F.; Liu, Z.-P. Angew. Chem., Int. Ed. Engl. 1994, 33, 1842-1844. (e) Lipshutz, B. H.; Liu, Z.-P.; Kayser, F. Tetrahedron Lett. 1994, 35, 5567-5570. (31) (a) Snyder, J . P.; Tipsword, G. E.; Spangler, D. P. J . Am. Chem. Soc. 1992, 114, 1507-1510. (b) Bertz, S. H.; Vellekoop, A. S.; Smith, R. A. J .; Snyder, J . P. Organometallics 1995, 14, 1213-1220. For theoretical studies on "lower order" cuprates see also: (c) Böhme, M.; Frenking, G.; Reetz, M. T. Organometallics 1994, 13, 4237-4245.

(32) Snyder, J . P.; Spangler, D. P.; Behling, J . R.; Rossiter, B. E. J . Org. Chem. 1994, 59, 2665-2667. 
monomeric in solution 33 and that two inequivalent methyl groups are present. ${ }^{34}$ These observations are in agreement with the solid-state and solution structure found for $\mathbf{6}$. This is an interesting comparative link, since it is the higher order cyanocuprate species which are capable of selectively generating biaryls through oxidation with molecular oxygen at low temperature. ${ }^{30}$

Moreover, ab initio calculations on $\left[\mathrm{Li}_{2} \mathrm{CuR}_{3}\right]$ higher order cuprates by Snyder et al. indicate that open structures such as that of $\mathbf{6}$ are more favorable than closed structures involving the presence of higher order tricoordinate copper species $\left[\mathrm{CuR}_{3}\right]^{2-} .31 \mathrm{a}, \mathrm{b}, 32$ The comparison in Figure 8 suggests that the functions of $\left[\mathrm{Cu}_{2}-\right.$ $\mathrm{Br}]^{+}$in $\mathbf{6}$, of $\left[\mathrm{Cu}_{3} \mathrm{Br}_{2}\right]^{+}$in $\mathbf{7}$ and $\mathbf{1 0}$, and of $\left[\mathrm{Li}_{2}(\mathrm{CN})\right]^{+}$in $\left[\mathrm{Li}_{2} \mathrm{Cu}(\mathrm{CN}) \mathrm{R}_{2}\right]$ are similar: i.e, they stabilize the $[\mathrm{CuR}]^{-}$ motive in the kinetically active species.

From this point of view, the cuprate species $\left[\mathrm{MgCu}_{4}{ }^{-}\right.$ $\left.\mathrm{Ph}_{6}\right],\left[\mathrm{LiCu}_{4} \mathrm{Ph}_{6}\right]^{-}$, and $\left[\mathrm{Cu}_{5} \mathrm{Ph}_{6}\right]^{-}$that do contain a tricoordinate copper atom can alternatively be described as comprising three units of $\left[\mathrm{CuPh}_{2}\right]^{-}$stabilized by combinations of $[\mathrm{MgCu}],[\mathrm{LiCu}]$, and $\left[\mathrm{Cu}_{2}\right]$ cations, respectively. Moreover, these medium-order cuprate species have structures similar to that of $\left[\mathrm{Li}_{2} \mathrm{Cu}_{3} \mathrm{Ph}_{6}\right]^{-}$, in which this tricoordinate copper is absent and that thus can be described as three [CuPh$]_{2}^{-}$anions stabilized by interaction with two $\mathrm{Li}^{+}$cations. ${ }^{35}$

\section{Conclusion}

The preparation of $\left[\mathrm{Cu}\left\{\mathrm{C}_{6} \mathrm{H}_{4}\left(\mathrm{CH}_{2} \mathrm{NMe}_{2}\right)-2\right\}_{4}\right]$ (3) through use of a copper (I) arenethiolate starting material is a novel route to aryl copper complexes that does not impose restrictions under experimental conditions (order of addition, solvent, temperature), and the chemistry of aggregates 6, 7 and 10 illustrates the stabilizing influence which intramolecular bidentate nitrogen ligands can exert on mixed arylcopper-copper bromide aggregates.

More importantly, the use of intramolecularly coordinating bidentate nitrogen ligands affords mixed arylcopper-copper bromide aggregates which comprise the lower order cuprate entity [CuAr $]_{2}^{-}$stabilized by a $\left[\mathrm{Cu}_{2}-\right.$ $\mathrm{Br}]^{+}$or a $\left[\mathrm{Cu}_{3} \mathrm{Br}_{2}\right]^{+}$cation. This description is substantiated by both structural features and the reactivity of these aggregates. These aggregates can be formally seen as the product of a reaction of the arylcopper CuAr with $\mathrm{CuBr}$ and a suitable $\mathrm{N}^{-} \mathrm{N}$ ligand (Scheme 2, path a).

Scheme 2 further illustrates the influence that ligands exert on the formation of particular aggregates. For example, the use of a neutral tridentate nitrogen ligand $\left(\mathrm{N}^{-} \mathrm{N}^{-} \mathrm{N}=\right.$ pmdta $=\mathrm{N}, \mathrm{N}, \mathrm{N}^{\prime}, \mathrm{N}^{\prime \prime}, \mathrm{N}^{\prime \prime}$-pentamethyl diethylenetriamine) with phenyl copper does not afford neutral aggregates but leads to the formation of the ionic species $\left[\mathrm{Cu}_{3} \mathrm{Ph}_{2}(\text { pmdta })_{2}\right]^{+}$and $\left[\mathrm{Cu}_{5} \mathrm{Ph}_{6}\right]^{-}$(Scheme 2, path b), ${ }^{36}$ whereas the use of neutral tridentate phos5317.

(33) Ashby, E. C.; Watkins, J . J . J . Am. Chem. Soc. 1977, 99, 5312-

(34) (a) Ashby, E. C.; Watkins, J .J .J . Chem. Soc., Chem. Commun. 1976, 784-785. (b) Bertz, S. H.; Dabbagh, G. J . Am. Chem. Soc. 1988, 110, 3668-3670.

(35) $\left[\mathrm{MgCu}_{4} \mathrm{Ph}_{6}\right]$ and $\left[\mathrm{LiCu}_{4} \mathrm{Ph}_{6}\right]^{-}$: (a) Khan, S. I.; Edwards, P. G.; Yuan, H. S. H.; Bau, R. J . Am. Chem. Soc. 1985, 107, 1682-1684. [Cu $5^{-}$ $\left.\mathrm{Ph}_{6}\right]^{-}$: (b) Edwards, P. G.; Gellert, R. W.; Marks, M. W.; Bau, R. J . Am. Chem. Soc. 1982, 104, 2072-2073. $\left[\mathrm{Li}_{2} \mathrm{Cu}_{3} \mathrm{Ph}_{6}\right]^{-}$: (c) Hope, $\mathrm{H}$.; Oram, D.; Power, P. P. J . Am. Chem. Soc. 1984, 106, 1149-1150.

(36) $\mathrm{He}, \mathrm{X}$.; Ruhlandt-Senge, K.; Power, P. P. J . Am. Chem. Soc. 1994, 116, 6963-6964.

\section{Scheme 2. Reaction of the Arylcopper Species CuAr with Various Ligands}

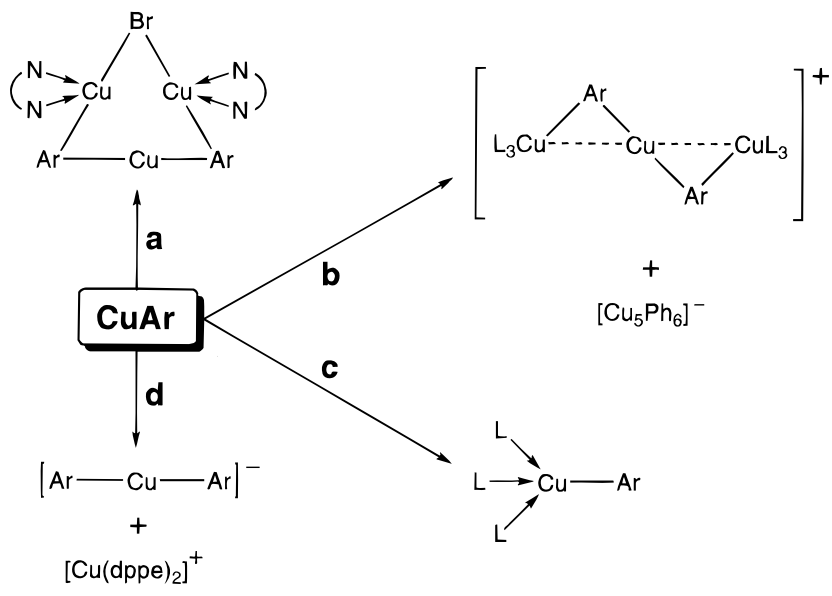

phine ligands $\left(\mathrm{P}^{-} \mathrm{P}^{-} \mathrm{P}=\mathrm{MeC}\left(\mathrm{CH}_{2} \mathrm{PPh}_{2}\right)_{3}\right)$ leads to the monomeric arylcopper complexes [CuPh( $\mathrm{MeC}\left(\mathrm{CH}_{2}-\right.$ $\left.\left.\mathrm{PPh}_{2}\right)_{3}\right)$ ] (Scheme 2, path c). ${ }^{37}$ Moreover, when $\mathrm{CuAr}$ $\left(\mathrm{Ar}=\mathrm{C}_{6} \mathrm{H}_{2} \mathrm{Me}_{3}-2,4,6\right)$ is treated with bidentate phosphines ( $\mathrm{P}^{-} \mathrm{P}=$ dppe) the ionic species $\left[\mathrm{CuAr}_{2}\right]^{-}$and $[\mathrm{Cu}$ (dppe) $\left.{ }_{2}\right]^{+}$are generated (Scheme 2, path d). ${ }^{17}$

We have now shown that aryl ligands with potentially bidentate nitrogen donor substituents are capable of stabilizing a $\left[\left\{\mathrm{CuR}_{2}\right\}\left\{\mathrm{Cu}_{2} \mathrm{Br}\right\}\right]$ assembly, with a specific biaryl coupling activity, rather than an ionic species in which the anionic and cationic sites are structurally isolated. One can now ask whether it is possible to obtain similar assemblies by using simple neutral bidentate nitrogen ligands such as tmeda and bipyridine. If this is so, a new class of reactive aggregates based on an arylcopper with copper bromide and a bidentate nitrogen ligand in various ratios might be possible. This aspect of arylcopper chemistry is a topic of current research.

\section{Experimental Section}

Syntheses were carried out using standard Schlenk techniques under an atmosphere of dry, oxygen-free nitrogen. Toluene, benzene, hexane, pentane, $\mathrm{Et}_{2} \mathrm{O}$, and $\mathrm{THF}$ were carefully dried and distilled from sodium benzophenone-ketyl prior to use. $\mathrm{CH}_{2} \mathrm{Cl}_{2}$ was distilled from calcium hydride. ${ }^{1 \mathrm{H}}$ and ${ }^{13} \mathrm{C}$ NMR spectra were recorded on a Bruker AC200 or AC300 spectrometer. Melting (decomposition) points were determined by using a Büchi melting point apparatus. Elemental analyses were carried out by Dornis und Kolbe, Mikroanalytisches Laboratorium, Mülheim a.d. Ruhr, Germany. [ $\left[\mathrm{Li}_{4}\left\{\mathrm{C}_{6} \mathrm{H}_{4}\left(\mathrm{CH}_{2} \mathrm{NMe}_{2}-2\right)\right\}_{4}\right]$ (1), ${ }^{9}\left[\mathrm{Cu}_{3}\left\{\mathrm{SC}_{6} \mathrm{H}_{4} \mathrm{NMe}_{2}-2\right\}_{3}\right]$ (2), ${ }^{10}$ and $\left[\mathrm{Li}_{2}\left\{\mathrm{C}_{6} \mathrm{H}_{4}\left(\mathrm{CH}_{2} \mathrm{~N}(\mathrm{Me}) \mathrm{CH}_{2} \mathrm{CH}_{2} \mathrm{NMe}_{2}-2\right)\right\}_{2}\right]$ (5) ${ }^{15}$ were synthesized according to literature procedures. 1- $\mathrm{BrC}_{10} \mathrm{H}_{6-}$ $\left(\mathrm{CH}_{2} \mathrm{~N}(\mathrm{Me}) \mathrm{CH}_{2} \mathrm{CH}_{2} \mathrm{NMe}_{2}\right)-2$ was prepared from 1-bromo-2bromomethylnaphthalene using a modified procedure for $\mathrm{BrC}_{6} \mathrm{H}_{4}\left(\mathrm{CH}_{2} \mathrm{~N}(\mathrm{Me}) \mathrm{CH}_{2} \mathrm{CH}_{2} \mathrm{NMe}_{2}\right)-2 .{ }^{15}$

Synthesis of $\left[\mathrm{Cu}_{4}\left\{\mathbf{C}_{6} \mathbf{H}_{\mathbf{4}}\left(\mathrm{CH}_{2} \mathrm{NMe}_{2}\right)-2\right\}_{4}\right]$ (3). ${ }^{12}$ To $\left[\mathrm{Cu}_{3^{-}}\right.$ $\left.\left\{\mathrm{SC}_{6} \mathrm{H}_{4} \mathrm{NMe}_{2}-2\right\}_{3}\right](2 ; 1.04 \mathrm{~g}, 4.82 \mathrm{mmol}$ of monomer) in benzene $(20 \mathrm{~mL})$ was slowly added $\left[\mathrm{Li}_{4}\left\{\mathrm{C}_{6} \mathrm{H}_{4}\left(\mathrm{CH}_{2} \mathrm{NMe}_{2}\right)-2\right\}_{4}\right](\mathbf{1} ; 0.68$ $\mathrm{g}, 4.82 \mathrm{mmol}$ of monomer) in THF $(10 \mathrm{~mL})$ at $25^{\circ} \mathrm{C}$. After this solution was stirred for $1 \mathrm{~h}$, the orange solution was evaporated to dryness in vacuo. Extraction of the solid with benzene $(3 \times 25 \mathrm{~mL})$ afforded a yellow solution which was evaporated in vacuo to yield $0.94 \mathrm{~g}(99 \%)$ of crude 3. Pure 3 was obtained by crystallization by slow diffusion of pentane

(37) Gambarotta, S.; Strologo, S.; Floriani, C.; Chiesi-Villa, A.; Guastini, C. Organometallics 1984, 3, 1444-1445. 
into a concentrated solution of $\mathbf{3}$ in toluene at $-20^{\circ} \mathrm{C}$. $\mathrm{Mp}$ : $178{ }^{\circ} \mathrm{C}$ dec. ${ }^{1} \mathrm{H}$ NMR (benzene- $\mathrm{d}_{6}, 200.13 \mathrm{MHz}, 297 \mathrm{~K}$ ): $\delta$ (in ppm) 1.92 (s, 6H, NMe $), 2.70\left(\mathrm{~s}, 2 \mathrm{H}, \mathrm{CH}_{2}\right), 6.83(\mathrm{~d}, 1 \mathrm{H}, 3 \mathrm{~J}=$ $7 \mathrm{~Hz}, \mathrm{Ar} \mathrm{H}-3), 7.09$ (t, $1 \mathrm{H}, 3 \mathrm{~J}=7 \mathrm{~Hz}, \mathrm{Ar} \mathrm{H}-4), 7.27$ (t, 1H, 3 $=7 \mathrm{~Hz}, \mathrm{Ar} \mathrm{H}-5), 8.48(\mathrm{~d}, 1 \mathrm{H}, 3 \mathrm{~J}=7 \mathrm{~Hz}, \mathrm{Ar} \mathrm{H}-6)$. Crystals of 3.THF suitable for an X-ray diffraction structure determination were obtained by cooling a solution of the crude reaction mixture (as obtained after evaporation) in $\mathrm{THF} / \mathrm{Et}_{2} \mathrm{O}$ (just enough THF was added to dissolve all solid material).

Synthesis of $\left[\mathrm{Cu}_{3} \mathrm{Br}\left\{\mathrm{C}_{6} \mathrm{H}_{4}\left(\mathrm{CH}_{2} \mathrm{~N}(\mathrm{Me}) \mathrm{CH}_{2} \mathrm{CH}_{2} \mathrm{NMe}_{2}\right)-2\right\}_{2}\right]$ (6). To a vigorously stirred suspension of $\mathrm{CuBr}(1.74 \mathrm{~g}, 12.1$ mmol) in $\mathrm{Et}_{2} \mathrm{O}(25 \mathrm{~mL})$ was added a solution of $\left[\mathrm{Li}_{2^{-}}\right.$ $\left.\left\{\mathrm{C}_{6} \mathrm{H}_{4}\left(\mathrm{CH}_{2} \mathrm{~N}(\mathrm{Me}) \mathrm{CH}_{2} \mathrm{CH}_{2} \mathrm{NMe}_{2}\right)-2\right\}_{2}\right](5 ; 1.60 \mathrm{~g}, 8.1 \mathrm{mmol}$ of monomer) in $\mathrm{Et}_{2} \mathrm{O}(50 \mathrm{~mL})$ at $0{ }^{\circ} \mathrm{C}$. After the reaction mixture was stirred at room temperature for $2 \mathrm{~h}$, all volatiles were evaporated in vacuo. Extraction of the solid material with benzene $(2 \times 40 \mathrm{~mL})$, subsequent evaporation of the volatiles in vacuo, and washing with pentane $(1 \times 15 \mathrm{~mL})$ yielded 2.60 $\mathrm{g}$ of greenish yellow $\mathbf{6}(99 \%, 4.0 \mathrm{mmol})$. Crystals suitable for X-ray structure determination were obtained by crystallization from $\mathrm{Et}_{2} \mathrm{O} /$ toluene at $-20{ }^{\circ} \mathrm{C}$. ${ }^{1} \mathrm{H}$ NMR (toluene- $\mathrm{d}_{8}, 200.13$ $\mathrm{MHz}, 263 \mathrm{~K}$ ): $\delta$ (in ppm) $0.8-2.9\left(\mathrm{~m}, 26 \mathrm{H}, \mathrm{N}(\mathrm{Me}) \mathrm{CH}_{2} \mathrm{CH}_{2}-\right.$ $\left.\mathrm{NMe}_{2}\right), 3.39\left(\mathrm{~d}, 1 \mathrm{H},{ }^{2} \mathrm{~J}=13 \mathrm{~Hz}, \mathrm{ArCH}_{2}\right), 3.77\left(\mathrm{br} \mathrm{s}, 2 \mathrm{H}, \mathrm{ArCH}_{2}\right)$, $3.8\left(\mathrm{br} \mathrm{d}, 1 \mathrm{H}, \mathrm{ArCH}_{2}\right), 6.65(\mathrm{~d}, 1 \mathrm{H}, 3 \mathrm{~J}=8 \mathrm{~Hz}, \mathrm{Ar} \mathrm{H}-3), 6.84(\mathrm{~d}$, $1 \mathrm{H}, 3 \mathrm{~J}=8 \mathrm{~Hz}, \operatorname{Ar~H}-3), 7.0-7.4(\mathrm{~m}, 4 \mathrm{H}, \operatorname{Ar~H}-4,5), 8.28(\mathrm{~d}$, $1 \mathrm{H}, 3 \mathrm{~J}=7 \mathrm{~Hz}, \operatorname{Ar} \mathrm{H}-6), 8.43(\mathrm{~d}, 1 \mathrm{H}, 3 \mathrm{~J}=7 \mathrm{~Hz}, \mathrm{Ar} \mathrm{H}-6)$.

Synthesis of $\left[\mathrm{Cu}_{4} \mathrm{Br}_{2}\left\{\mathrm{C}_{6} \mathrm{H}_{4}\left(\mathrm{CH}_{2} \mathrm{~N}(\mathrm{Me}) \mathrm{CH}_{2} \mathrm{CH}_{2} \mathrm{NMe}_{2}\right)-\right.\right.$ 2\} 2] (7). The synthesis of $\mathbf{7}$ is similar to that of $\mathbf{6}$ but starts from $\mathrm{CuBr}(0.78 \mathrm{~g}, 5.44 \mathrm{mmol})$ in $\mathrm{Et}_{2} \mathrm{O}(25 \mathrm{~mL})$ and $\mathbf{5}(0.55 \mathrm{~g}$, $2.77 \mathrm{mmol})$ in $\mathrm{Et}_{2} \mathrm{O}(50 \mathrm{~mL})$. Yield of 7: $0.49 \mathrm{~g}(89 \%, 1.23$ $\mathrm{mmol}$ ). Crystalline $\mathbf{7}$ could be obtained by slow diffusion of pentane into a saturated toluene solution of 7 at $-20{ }^{\circ} \mathrm{C}$. Mp: $125-127^{\circ} \mathrm{C}$ dec. ${ }^{1} \mathrm{H}$ NMR (toluene-d $, 200.13 \mathrm{MHz}, 263$ $\mathrm{K}): \delta$ (in ppm) major isomer $1.04\left(\mathrm{~s}, 6 \mathrm{H}, \mathrm{NMe}_{2}\right), 2.17(\mathrm{~s}, 6 \mathrm{H}$, $\mathrm{NMe}_{2}$ ), 2.37 (s, 3H, NMe), 2.47 (s, 3H, NMe), 2.51 (d, 1H, ${ }^{2} \mathrm{~J}=$ $\left.12 \mathrm{~Hz}, \mathrm{ArCH}_{2}\right), 2.71\left(\mathrm{~d}, 1 \mathrm{H}, \mathrm{j}=12 \mathrm{~Hz}, \mathrm{ArCH}_{2}\right), 3.39(\mathrm{~d}, 1 \mathrm{H}$, 2) $\left.=12 \mathrm{~Hz}, \mathrm{ArCH}_{2}\right), 3.81\left(\mathrm{~d}, 1 \mathrm{H},{ }^{2} \mathrm{~J}=12 \mathrm{~Hz}, \mathrm{ArCH}_{2}\right), 6.63(\mathrm{~d}$, $1 \mathrm{H}, 3 \mathrm{~J}=7 \mathrm{~Hz}, \mathrm{Ar} \mathrm{H}-3), 6.85(\mathrm{~d}, 1 \mathrm{H}, 3 \mathrm{~J}=7 \mathrm{~Hz}, \mathrm{Ar} \mathrm{H}-3), 6.9-$ 7.4 (m, Ar H-4,5), 8.28 (d, $1 \mathrm{H}, 3 \mathrm{~J}=7 \mathrm{~Hz}, \operatorname{Ar~H}-6), 8.42$ (d, $1 \mathrm{H}$, 3j $=7 \mathrm{~Hz}, \mathrm{Ar} \mathrm{H}-6)$; minor isomer, $2.88\left(\mathrm{~d}, 1 \mathrm{H}, \mathrm{2}^{2} \mathrm{~J}=12 \mathrm{~Hz}\right.$, $\left.\mathrm{ArCH}_{2}\right), 4.22\left(\mathrm{~d}, 1 \mathrm{H},{ }^{2} \mathrm{~J}=12 \mathrm{~Hz}, \mathrm{ArCH}_{2}\right), 6.85\left(\mathrm{~d}, 1 \mathrm{H}, \mathrm{2}^{\mathrm{J}}=7\right.$ $\mathrm{Hz}, \mathrm{Ar} \mathrm{H}-6), 8.57\left(\mathrm{~d}, 1 \mathrm{H}, \mathrm{2}^{\mathrm{J}}=6 \mathrm{~Hz}, \mathrm{Ar} \mathrm{H}-6\right)$. The signals of the $\mathrm{CH}_{2} \mathrm{CH}_{2}$ groups of both species are poorly resolved and reside between 0.7 and $2.5 \mathrm{ppm}$. Other signals from the minor species could not be assigned due to severe overlap with the major species (see text). Anal. Calcd for $\mathrm{C}_{24} \mathrm{H}_{38} \mathrm{~N}_{4} \mathrm{Cu}_{4} \mathrm{Br}_{2}$ : C, 36.19; H, 4.81; N, 7.03. Found: C, 36.19; H, 4.93; N, 6.85 .

Synthesis of [Li $\left\{1-\mathrm{C}_{10} \mathrm{H}_{6}\left(\mathrm{CH}_{2} \mathrm{~N}(\mathrm{Me}) \mathrm{CH}_{2} \mathrm{CH}_{2} \mathrm{NMe}_{2}\right)-2\right\}$ ] (9). To a stirred solution of $\mathrm{BrC}_{10} \mathrm{H}_{6}\left(\mathrm{CH}_{2} \mathrm{~N}(\mathrm{Me}) \mathrm{CH}_{2} \mathrm{CH}_{2^{-}}\right.$ $\left.\mathrm{NMe}_{2}\right)-2(3.99 \mathrm{~g}, 12.4 \mathrm{mmol})$ in pentane $(50 \mathrm{~mL})$ was slowly added ${ }^{\mathrm{n}} \mathrm{BuLi}$ in hexane $(7.75 \mathrm{~mL}$ of a $1.6 \mathrm{M}$ solution in hexane, $12.4 \mathrm{mmol}$ ) at $0{ }^{\circ} \mathrm{C}$. After $2 \mathrm{~h}$ the white precipitate was isolated by centrifugation and subsequent washing with pentane $(1 \times 25 \mathrm{~mL})$. Yield: $2.12 \mathrm{~g}(69 \%)$ of 9. ${ }^{1} \mathrm{H}$ NMR (benzene$\mathrm{d}_{6}, 200.13 \mathrm{MHz}$ ): $\delta$ (in ppm) 1.14 (ddd, $1 \mathrm{H},{ }^{2} \mathrm{~J}=-12.89 \mathrm{~Hz}$, 3) $=3.34 \mathrm{~Hz}, 3 \mathrm{~J}=2.87 \mathrm{~Hz}, \mathrm{CH}^{c} \mathrm{HCH}_{2}$ ), $1.36\left(\mathrm{ddd}, 1 \mathrm{H},{ }^{2} \mathrm{j}=\right.$ $\left.-13.08 \mathrm{~Hz}, 3 \mathrm{~J}=3.34 \mathrm{~Hz}, 3 \mathrm{~J}=3.19 \mathrm{~Hz}, \mathrm{CH}_{2} \mathrm{CH}^{\mathrm{b}} \mathrm{H}_{2}\right), 1.38$ (s, $\left.6 \mathrm{H}, \mathrm{NMe}_{2}\right), 1.76\left(\mathrm{td}, 1 \mathrm{H}, 2 \mathrm{~J}=-12.89 \mathrm{~Hz},{ }^{3} \mathrm{~J}=12.90 \mathrm{~Hz}, 3 \mathrm{~J}=\right.$ $3.19 \mathrm{~Hz}, \mathrm{CH}^{\mathrm{d}} \mathrm{HCH}_{2}$ ), 2.19 (s, 3H, NMe), 2.70 (td, 1H, 2J = $-13.08 \mathrm{~Hz}$, 3J $=12.90 \mathrm{~Hz}$, 3j $\left.=2.87 \mathrm{~Hz}, \mathrm{CH}_{2} \mathrm{CHH}^{\mathrm{a}}\right), 3.39$ (d, $\left.1 \mathrm{H},{ }^{2} \mathrm{~J}=12 \mathrm{~Hz}, \mathrm{ArCH}_{2}\right), 4.56\left(\mathrm{~d}, 1 \mathrm{H},{ }^{2} \mathrm{~J}=12 \mathrm{~Hz}, \mathrm{ArCH}_{2}\right), 7.39$ $(\mathrm{d}, 1 \mathrm{H}, 3 \mathrm{~J}=8 \mathrm{~Hz}, \mathrm{Ar} \mathrm{H}), 7.49(\mathrm{t}, 1 \mathrm{H}, 3 \mathrm{~J}=7 \mathrm{~Hz}, \mathrm{Ar} \mathrm{H}), 7.61(\mathrm{t}$, $1 \mathrm{H}$, 3 $=7 \mathrm{~Hz}, \operatorname{Ar} \mathrm{H}), 7.84(\mathrm{~d}, 1 \mathrm{H}, 3 \mathrm{~J}=8 \mathrm{~Hz}, \operatorname{Ar~H}), 8.01(\mathrm{~d}$, $1 \mathrm{H}, 3 \mathrm{~J}=8 \mathrm{~Hz}, \operatorname{Ar} \mathrm{H}), 8.69(\mathrm{~d}, 1 \mathrm{H}, 3 \mathrm{~J}=8 \mathrm{~Hz}, \mathrm{Ar} \mathrm{H})$. Karplus analysis of $\mathbf{9}$ was carried out using data with a digital resolution of $0.29 \mathrm{~Hz} /$ point after spectral simulation with the program gNMR from Cherwell Scientific Publishing. Estimated standard deviation values in J are $\pm 0.3 \mathrm{~Hz}$, leading to an estimated error in $\omega$ of $2^{\circ}$ and in $\mathrm{n}_{\lambda}$ of $2 \%$, respectively.

Synthesis of $\left[\mathrm{Cu}_{4} \mathrm{Br}_{2}\left\{1-\mathrm{C}_{10} \mathrm{H}_{6}\left(\mathrm{CH}_{2} \mathrm{~N}(\mathrm{Me}) \mathrm{CH}_{2} \mathrm{CH}_{2} \mathrm{NMe}_{2}\right)-\right.\right.$ 2\}2] (10). A suspension of $\mathrm{CuBr}(0.82 \mathrm{~g}, 5.72 \mathrm{mmol})$ in $\mathrm{Et}_{2} \mathrm{O}$
(25 $\mathrm{mL}$ ) was added slowly to freshly prepared [Li\{1$\left.\mathrm{C}_{10} \mathrm{H}_{6}\left(\mathrm{CH}_{2} \mathrm{~N}(\mathrm{Me}) \mathrm{CH}_{2} \mathrm{CH}_{2} \mathrm{NMe}_{2}\right)-2\right\}$ ] (9; $\left.0.83 \mathrm{~g}, 3.34 \mathrm{mmol}\right)$ in $\mathrm{Et}_{2} \mathrm{O}(50 \mathrm{~mL})$ at $0{ }^{\circ} \mathrm{C}$. After the mixture was stirred for $3 \mathrm{~h}$ at $25^{\circ} \mathrm{C}$, all volatiles were removed in vacuo. Extraction of the solid with benzene $(3 \times 50 \mathrm{~mL})$ and subsequent removal of the volatiles in vacuo yielded $1.10 \mathrm{~g}$ ( $85 \%$ on $\mathrm{CuBr}$ ) of slightly greenish powder. Crystallization by slow diffusion of hexane into a toluene solution of $\mathbf{1 0}$ at $-20{ }^{\circ} \mathrm{C}$ afforded crystals suitable for $\mathrm{X}$-ray structure determination. $\mathrm{Mp}: 125^{\circ} \mathrm{C}$. $\mathrm{T}_{\text {dec }}$ $=152^{\circ} \mathrm{C}$. ${ }^{1} \mathrm{H}$ NMR (benzene- $\mathrm{d}_{6}, 200.13 \mathrm{MHz}, 297 \mathrm{~K}$ ): $\delta$ (in ppm) 0.61 (s, 3H, NMe), 0.8-1.0 (m, $\left.1 \mathrm{H}, \mathrm{CH}_{2} \mathrm{CH}_{2}\right), 1.2-1.6$ $\left(\mathrm{m}, 1 \mathrm{H}, \mathrm{CH}_{2} \mathrm{CH}_{2}\right), 1.7-2.08\left(\mathrm{~m}, 2 \mathrm{H}, \mathrm{CH}_{2} \mathrm{CH}_{2}\right), 2.08(\mathrm{~s}, 3 \mathrm{H}$, $\mathrm{NMe}), 2.33$ (s, 3H, N(Me)), $2.44\left(\mathrm{~d}, 1 \mathrm{H},{ }^{2} \mathrm{~J}=12 \mathrm{~Hz}, \mathrm{ArCH}_{2}\right.$ ), $2.94\left(\mathrm{~d}, 1 \mathrm{H},{ }^{2} \mathrm{~J}=12 \mathrm{~Hz}, \mathrm{ArCH}_{2}\right), 6.61(\mathrm{~d}, 1 \mathrm{H}, 3 \mathrm{~J}=8 \mathrm{~Hz}, \mathrm{Ar}$ $\mathrm{H}-3), 7.32(\mathrm{~d}+\mathrm{t}, 2 \mathrm{H}, \mathrm{Ar} \mathrm{H}-5,6), 7.61(\mathrm{~d}+\mathrm{t}, 2 \mathrm{H}, \mathrm{Ar} \mathrm{H}-4,7), 9.38$ (d, $1 \mathrm{H},{ }_{3}^{3}=8 \mathrm{~Hz}$, Ar $\mathrm{H}-8$ ). Anal. Calcd for $\mathrm{C}_{32} \mathrm{H}_{42} \mathrm{~N}_{4} \mathrm{Cu}_{4}$ $\mathrm{Br}_{2} \cdot \mathrm{C}_{7} \mathrm{H}_{8}$ : C, 47.37; $\mathrm{H}, 5.10 ; \mathrm{N}, 5.67$. Found: $\mathrm{C}, 47.66 ; \mathrm{H}, 5.42$; N, 5.65 .

Synthesis of the Biaryl Species $\left(\mathrm{C}_{6} \mathrm{H}_{4}\left(\mathrm{CH}_{2} \mathrm{~N}(\mathrm{Me})\right.\right.$ $\left.\left.\mathrm{CH}_{2} \mathrm{CH}_{2} \mathrm{NMe}_{2}\right)-2\right)_{2}$ (8). A solution of $\mathbf{6}(3.82 \mathrm{~g}, 5.8 \mathrm{mmol})$ in toluene $(50 \mathrm{~mL})$ was stirred at reflux for $19 \mathrm{~h}$. The solution was acidified with a $4 \mathrm{M} \mathrm{HCl}$ solution in water to a $\mathrm{pH}$ of \pm 1 and, after it was stirred for $10 \mathrm{~min}$, made alkaline with a concentrated $\mathrm{NaOH}$ solution to a $\mathrm{pH}$ of \pm 12 ; a yellow solid precipitated. Separation of the solid by centrifugation and subsequent decantation, followed by evaporation of the volatiles in vacuo, yielded $0.82 \mathrm{~g}$ of $\mathbf{8}(38 \%)$. Pure $\mathbf{8}$ can be obtained by flash distillation. ${ }^{1} \mathrm{H}$ NMR (benzene- $\mathrm{d}_{6}, 300.13 \mathrm{MHz}$ ): $\delta$ (in ppm) 2.05 (s, 12H, NMe $), 2.08$ (s, 6H, NMe), 2.22 (t, 4H, 3J $\left.=8 \mathrm{~Hz}, \mathrm{NCH}_{2}\right), 2.37\left(\mathrm{t}, 4 \mathrm{H}, 3 \mathrm{~J}=8 \mathrm{~Hz}, \mathrm{NCH}_{2}\right), 3.25(\mathrm{~d}, 2 \mathrm{H}$, 2J $\left.=14 \mathrm{~Hz}, \operatorname{ArCH}_{2}\right), 3.41\left(\mathrm{~d}, 2 \mathrm{H},{ }^{2} \mathrm{~J}=14 \mathrm{~Hz}, \mathrm{ArCH}_{2}\right), 7.11-$ $7.22\left(\mathrm{~m}, 6 \mathrm{H}, \operatorname{Ar~H}-3,3^{\prime}, 4,4^{\prime}, 5,5^{\prime}\right), 7.76(\mathrm{~d}, 2 \mathrm{H}, 3 \mathrm{~J}=7 \mathrm{~Hz}, \mathrm{Ar}$ $\left.\mathrm{H}-6,6^{\prime}\right) .{ }^{13} \mathrm{C}$ NMR (benzene-d $6,75.47 \mathrm{MHz}$ ): $\delta$ (in ppm) 42.8 (NMe), $46.0\left(\mathrm{NMe}_{2}\right), 56.4\left(\mathrm{CH}_{2}\right), 58.3\left(\mathrm{CH}_{2}\right), 60.3\left(\mathrm{ArCH}_{2}\right)$,

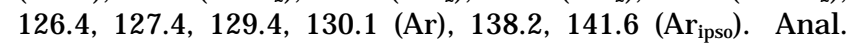
Calcd for $\mathrm{C}_{24} \mathrm{H}_{38} \mathrm{~N}_{4}$ : C, 75.34; $\mathrm{H}, 10.01 ; \mathrm{N}, 14.64$. Found: C, 75.43; H, 10.10; N, 14.71.

Synthesis of the Binaphthyl Species $\left(1-\mathrm{C}_{10} \mathrm{H}_{6}\left(\mathrm{CH}_{2} \mathrm{~N}-\right.\right.$ (Me) $\mathrm{CH}_{2} \mathrm{CH}_{2} \mathrm{NMe}_{2}$ )-2) $)_{2}$ (11). The synthesis of binaphthyl 11 is identical with that of biaryl $\mathbf{8}$ but starts from $\mathbf{1 0}(0.69 \mathrm{~g}$, $0.77 \mathrm{mmol})$ in toluene $(50 \mathrm{~mL})$ at reflux for $19 \mathrm{~h}$. Yield: 0.35 g (94\%) of a brown oil containing $42 \%$ of 11 and $58 \%$ of $\mathrm{C}_{10} \mathrm{H}_{7}\left(\mathrm{CH}_{2} \mathrm{~N}(\mathrm{Me}) \mathrm{CH}_{2} \mathrm{CH}_{2} \mathrm{NMe}_{2}\right.$ )-2 (produced from hydrolysis of 10 during workup). ${ }^{1} \mathrm{H}$ NMR (benzene- $\mathrm{d}_{6}, 200.13 \mathrm{MHz}$ ): $\delta$ (in ppm) 2.03 (s, 12H, NMe $), 2.21(\mathrm{~s}, 6 \mathrm{H}, \mathrm{NMe}), 2.3-2.6\left(\mathrm{~m}, \mathrm{CH}_{2-}\right.$ $\left.\mathrm{CH}_{2}\right), 3.19\left(\mathrm{~d}, 2 \mathrm{H},{ }^{2} \mathrm{~J}=14 \mathrm{~Hz}, \mathrm{ArCH}_{2}\right), 3.50\left(\mathrm{~d}, 2 \mathrm{H},{ }^{2} \mathrm{~J}=14\right.$ $\left.\mathrm{Hz}, \mathrm{ArCH}_{2}\right), 6.9-7.4(\mathrm{~m}, \mathrm{Ar} \mathrm{H}), 7.5-7.8(\mathrm{~m}, \mathrm{Ar} \mathrm{H}), 7.88(\mathrm{~d}$, $2 \mathrm{H}, 3 \mathrm{~J}=9 \mathrm{~Hz}, \operatorname{Ar} \mathrm{H}), 8.23\left(\mathrm{~d}, 2 \mathrm{H}, 3 \mathrm{~J}=9 \mathrm{~Hz}, \operatorname{Ar} \mathrm{H}-6,6^{\prime}\right)$. Integrals for the $\mathrm{CH}_{2} \mathrm{CH}_{2}$ and aromatic multiplets were not exactly determined due to overlap with the signals of $\mathrm{C}_{10} \mathrm{H}_{7}\left(\mathrm{CH}_{2} \mathrm{~N}(\mathrm{Me}) \mathrm{CH}_{2} \mathrm{CH}_{2} \mathrm{NMe}_{2}\right)-2$.

Structure Determination and Refinement of 3.THF, 6, and $\mathbf{1 0}_{0} \mathrm{C}_{7} \mathbf{H}_{8} . \mathrm{X}$-ray data were collected on an Enraf-Nonius CAD4T rotating anode diffractometer for a transparent yellow (3 and 6) or brownish (10) crystal glued on top of a glass fiber. Accurate unit cell parameters and an orientation matrix were derived from the setting angles of 25 well-centered reflections (SET4) 38 in the range $11^{\circ}<\theta<14.5^{\circ}$. The unit cell parameters were checked for the presence of higher lattice symmetry. ${ }^{39}$ Data were corrected for Lorentz-polarization effects. An empirical absorption correction was applied (DIFABS, 40 as implemented in PLATON ${ }^{41}$ ). The structure was solved by direct methods (SHELXS ${ }^{42}$ for $\mathbf{3}$ and $\mathbf{6}$ ) or automated Patterson

C410.

(39) Spek, A. L. J . Appl. Crystallogr. 1988, 21, 578.

(40) Walker, N.; Stuart, D. Acta Crystallogr. 1983, A39, 158-166.

(41) Spek, A. L. Acta Crystallogr. 1990, A46, C34.

(42) Sheldrick, G. M. SHELXS86: Program for Crystal Structure Determination; University of Göttingen, Göttingen, Germany, 1986. 
Table 4. Experimental Data for the X-ray Diffraction Studies of 3, 6, and 10

\begin{tabular}{|c|c|c|c|}
\hline & 3 & 6 & 10 \\
\hline $\begin{array}{l}\text { formula } \\
\text { fw }\end{array}$ & $\begin{array}{l}\mathrm{C}_{36} \mathrm{H}_{48} \mathrm{~N}_{4} \mathrm{Cu}_{4} \cdot \mathrm{C}_{4} \mathrm{H}_{8} \mathrm{O} \\
863.09\end{array}$ & $\begin{array}{l}\mathrm{C}_{24} \mathrm{H}_{38} \mathrm{~N}_{4} \mathrm{BrCu}_{3} \\
653.19\end{array}$ & $\begin{array}{l}\mathrm{C}_{32} \mathrm{H}_{42} \mathrm{~N}_{4} \mathrm{Br}_{2} \mathrm{Cu}_{4} \cdot \mathrm{C}_{7} \mathrm{H}_{8} \\
988.84\end{array}$ \\
\hline cryst syst & monoclinic & monoclinic & orthorhombic \\
\hline space group & $\mathrm{C} 2 / \mathrm{C}$ & $\mathrm{P} 2_{1} / \mathrm{C}$ & $\mathrm{Pna}_{1}$ \\
\hline a $(\AA)$ & 17.144(1) & $11.1272(7)$ & $24.175(1)$ \\
\hline$b(\AA)$ & $13.3598(7)$ & $15.411(1)$ & $10.5431(7)$ \\
\hline$c(\AA)$ & $17.206(1)$ & $18.4512(9)$ & $15.568(2)$ \\
\hline$\beta$ (deg) & $91.689(5)$ & $123.376(5)$ & \\
\hline$V\left(\AA^{3}\right)$ & $3939.0(4)$ & $2642.2(3)$ & $3967.9(6)$ \\
\hline $\mathrm{Z}$ & 4 & 4 & 4 \\
\hline$d_{\text {calc }}\left(\mathrm{g} \mathrm{cm}^{-3}\right)$ & 1.455 & 1.642 & 1.655 \\
\hline$\mu(\operatorname{MoK} \alpha)\left(\mathrm{cm}^{-1}\right)$ & 21.7 & 39.2 & 41.6 \\
\hline cryst size (mm) & $0.38 \times 0.50 \times 0.60$ & $0.20 \times 0.20 \times 0.60$ & $0.30 \times 0.30 \times 0.40$ \\
\hline radiation $(\AA)$ & $\operatorname{MoK} \alpha(0.71073)^{a}$ & $\operatorname{MoK} \alpha(0.71073)^{a}$ & $\operatorname{MoK} \alpha(0.71073)^{a}$ \\
\hline $\operatorname{scan}(\omega-2 \theta)(\mathrm{deg})$ & $0.66+0.35 \tan \theta$ & $0.54+0.35 \tan \theta$ & $0.67+0.35 \tan \theta$ \\
\hline$\theta^{\min }, \theta^{\max }(\mathrm{deg})$ & $1.19,27.50$ & $1.32,27.50$ & $1.70,27.50$ \\
\hline temp (K) & 150 & 150 & 150 \\
\hline decay (\%), X-ray time (h) & 3,18 & 1,18 & $<1,19$ \\
\hline $\mathrm{hkl}(\min , \max )$ & $-22,+22 ;-17,0 ;-22,+18$ & $-14,+14 ; 0,20 ;-20,+19$ & $-31,+31 ;-13,0 ;-20,+13$ \\
\hline total/unique no. of rflns & $7849,4507\left(R_{\mathrm{av}}=0.020\right)$ & $6910,6047\left(\mathrm{R}_{\mathrm{av}}=0.185\right)$ & $9357,4751\left(R_{a v}=0.065\right)$ \\
\hline no. of obsd rflns & $3820(\mathrm{~F}>4 \sigma(\mathrm{F}))^{\mathrm{b}}$ & $4362(\mathrm{~F}>4 \sigma(\mathrm{F}))^{\mathrm{b}}$ & $3143(\mathrm{~F}>4 \sigma(\mathrm{F}))^{\mathrm{b}}$ \\
\hline DIFABS $(\min , \max )^{c}$ & $0.872,1.121$ & $0.839,1.254$ & $0.816,1.342$ \\
\hline $\mathrm{N}_{\text {ref }}, \mathrm{N}_{\mathrm{par}}$ & 4507,227 & 6047, 289 & 4751,449 \\
\hline$R 1^{d}$ & 0.0282 & 0.0497 & 0.0469 \\
\hline$w R 2^{d}$ & 0.0657 & 0.1286 & 0.0646 \\
\hline & 1.01 & 1.04 & 0.94 \\
\hline $\begin{array}{l}\text { weight }\left(w^{-1}\right)^{e} \\
\text { min, max resd dens }\left(e \AA^{-3}\right)\end{array}$ & $\begin{array}{l}\sigma^{2}\left(\mathrm{~F}_{0}^{2}\right)+(0.296 \mathrm{P})^{2}+4.11 \mathrm{P} \\
-0.37,0.47\end{array}$ & $\begin{array}{l}\sigma^{2}\left(\mathrm{Fo}_{\mathrm{o}}^{2}\right)+(0.0620 \mathrm{P})^{2}+3.39 \mathrm{P} \\
-1.48,0.89\end{array}$ & $\begin{array}{l}\sigma^{2}\left(\mathrm{Fo}_{\mathrm{o}}^{2}\right)+(0.0140 \mathrm{P})^{2} \\
-0.47,0.51\end{array}$ \\
\hline
\end{tabular}

methods (DIRDIF $92^{43}$ for 10) and subsequent difference $F$ ourier techniques. Refinement on $\mathrm{F}^{2}$ was carried out by fullmatrix least-squares techniques (SHELXL 93 ${ }^{44}$ ). The correct polarity adopted for the structure of $\mathbf{1 0}$ was indicated by the Flack parameter ${ }^{45}$ value of $0.01(1)$. All non-hydrogen atoms were refined with anisotropic atomic displacement parameters. The $\mathrm{C}$ atoms of the THF molecule in $\mathbf{3}$ were refined with isotropic atomic displacement parameters, since the THF is disordered around the 2-fold rotation axis. Hydrogen atoms were included on calculated positions $(\mathrm{C}-\mathrm{H}=0.98 \AA)$, riding on their carrier atoms and refined with a fixed isotropic atomic displacement parameter amounting to 1.5 times (methyl groups) or 1.2 times $\left(\mathrm{CH}_{2}\right.$ and aromatic hydrogen atoms) the value of the equivalent isotropic atomic displacement parameter of their carrier atom. Weights were optimized in the final refinement cycles. Neutral atom scattering factors and anomalous dispersion corrections were taken from ref 46 . Geometrical calculations and illustrations were performed with

(43) Beurskens, P. T.; Admiraal, G.; Beurskens, G.; Bosman, W. P.; García-Granda, S.; Gould, R. O.; Smits, J . M. M.; Smykalla, C. The DIRDIF Program System, Technical Report of the Crystallography Laboratory; University of Nijmegen, Nijmegen, The Netherlands, 1992. (44) Sheldrick, G. M. SHELXL93. Program for Crystal Structure Refinement; University of Göttingen, Göttingen, Germany, 1993.

(45) Flack, H. D. Acta Crystallogr. 1983, A39, 876-881.
PLATON; $; 1$ all calculations were performed on a DEC5000 cluster. Crystal data and details on data collection and refinement are collected in Table 4. Selected geometrical details of the structures of $\mathbf{3 , 6}$, and $\mathbf{1 0}$ are listed in Tables $1-3$, respectively.

Acknowledgment. This work was supported in part (A.L.S.) by the Netherlands Foundation for Chemical Research (SON), with financial aid from the Netherlands Organization for Scientific Research (NWO).

Supporting Information Available: Tables of crystal data and refinement details, positional and thermal parameters, and all bond distances and angles for 3, 6, and 10 (25 pages). This material is contained in many libraries on microfiche, immediately follows this article in the microfilm version of the journal, can be ordered from the ACS, and can be downloaded from the Internet; see any current masthead page for ordering information and I nternet access instructions.

\section{OM9600506}

(46) Wilson, A. J . C., Ed. International Tables for Crystallography; Kluwer Academic: Dordrecht, The Netherlands, 1992; Vol. C. 